\title{
RADIOLOGICAL IMPACT OF 1993 OPERATIONS AT THE SAVANNAH RIVER SITE
}

A. A. Simpkins $A / 5$

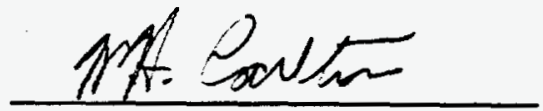

Technical Reviewer

\section{DISCLAIMER}

June 1994

This report was prepared as an account of work sponsored by an agency of the United States Government. Neither the United States Government nor any agency thereof, nor any of their employees, makes any warranty, express or implied, or assumes any legal liability or responsibility for the accuracy, completeness, or usefulness of any information, apparatus, product, or process disclosed, or represents that its use would not infringe privately owned rights. Reference herein to any specific commercial product, process, or service by trade name, trademark, manufacturer, or otherwise does not necessarily constitute or imply its endorsement, recommendation, or favoring by the United States Government or any agency thereof. The views and opinions of authors expressed herein do not necessarily state or reflect those of the United States Government or any agency thereof.

Westinghouse Savannah River Company

Savannah River Site

Aiken, SC 29808

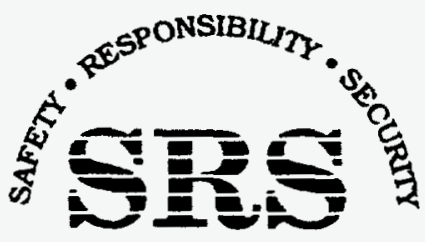

SAVANNAH RIVER SITE

PREPARED FOR THE U.S. DEPARTMENT OF ENERGY UNDER CONTRACT NO. DE-ACO9-89SR18035 


\section{DISCLAIMER}

This report was prepared as an account of work sponsored by an agency of the United States Government. Neither the United States Government nor any agency thereof, nor any of their employees, makes any warranty, express or implied, or assumes any legal liability or responsibility for the accuracy, completeness, or usefulness of any information, apparatus, product, or process disclosed, or represents that its use would not infringe privately owned rights. Reference herein to any specific commercial product, process, or service by trade name, trademark, manufacturer, or otherwise does not necessarily constitute or imply its endorsement, recommendation, or favoring by the United States Government or any agency thereof. The views and opinions of authors expressed herein do not necessarily state or reflect those of the United States Government or any agency thereof.

This report has been reproduced directly from the best available copy.

Available to DOE and DOE contractors from the Office of Scientific and Technical Information, P.O. Box 62, Oak Ridge, TN 37831; prices available from (615) 576-8401.

Available to the public from the National Technical Information Service, U.S. Department of Commerce; 5285 Port Royal Road, Springfield, VA 22161. 


\section{DISCLAIMER}

Portions of this document may be illegible in electronic image products. Images are produced from the best available original document. 


\title{
RADIOLOGICAL IMPACT OF 1993 OPERATIONS AT THE SAVANNAH RIVER SITE
}

\author{
A.A. Simpkins \\ Savannah River Technology Center \\ Westinghouse Savannah River Company \\ Aiken, South Carolina 29808
}

\section{Executive Summary}

An offsite individual residing at the SRS boundary at the point of the maximum exposure (maximum individual) received a dose of 0.11 mrem from SRS atmospheric releases in 1993 (See Table 1 for a 5-yr history of doses). This dose was only $1.1 \%$ of the EPA public dose limit of $10 \mathrm{mrem} / \mathrm{yr}$ (DOE, 1990). Tritium oxide releases were responsible for $90 \%$ of the atmospheric dose. Ninety-nine percent of the atmospheric dose was accounted for with the inclusion of $\mathrm{I}-129, \mathrm{U}-235, \mathrm{U}-238, \mathrm{Pu}-238$ and Pu-239. The 50mile population received a collective dose of 7.6 person-rem from 1993 atmospheric releases. Ninety-nine percent of this dose also resulted from the release of the same isotopes that dominated the maximum individual dose due to atmospheric releases. For both the individual and the population, atmospheric radiation dose was dominated by the inhalation and vegetation consumption pathways.

The maximum dose received by an offsite individual as a result of SRS liquid releases in 1993 was 0.14 mrem (See Table 1 for a 5-yr history). This does was only $3.5 \%$ of the EPA limit for drinking water of 4 mrem/yr (DOE, 1990). This dose was dominated by Cs-137 accumulated in Savannah River fish and tritium in drinking water. More than $99 \%$ of the maximum individual dose from liquid releases resulted from tritium, Sr-90, Cs-137, and Pu-239. The population dose from liquid releases in 1993 was 1.5 person-rem. Again, tritium, Sr-90, Cs-137, and Pu-239 contributed more than $99 \%$ of this dose. The major exposure pathway to the population was drinking water.

Radiation dose to the general public from operations at the Savannah River Site continued to be a very small fraction of the natural background dose. A resident of the CSRA receives about 300 mrem per year from background radiation. The population within $80 \mathrm{~km}$ of the SRS $(620,000)$ and $a$ the downstream water treatment facilities $(65,000)$, therefore, received a natural background population dose of approximately 200,000 person-rem during 1993.

All information concerning release amounts and doses was taken from (Cariton, 1994).

Table 1. Five-Year History of Offsite Dose from SRS Operations

$\begin{array}{lllll}1989 & 1990 & 1991 & 1992 & 1993\end{array}$

Atmospheric Releases

Max. Individual (mrem)

Population (person-rem)
0.31

17
0.16

9.6
0.12

7.1
0.09

6.4
0.11

7.6

\section{Liqnid Releases}

Max. Individual (mrem)

Max. Ind. Beaufort-Jasper

Max. Ind. Port Wentworth

Population (person-rem)

\begin{tabular}{lllll}
0.30 & 0.17 & 0.34 & 0.13 & 0.14 \\
0.12 & 0.061 & 0.081 & 0.070 & 0.038 \\
0.12 & 0.074 & 0.099 & 0.087 & 0.051 \\
4.8 & 2.4 & 3.2 & 2.5 & 1.5 \\
\hline
\end{tabular}




\section{ATMOSPHERIC RELEASES}

Table 2 shows the atmospheric releases by nuclide and facility. The total amount of tritium released to the atmosphere was 191,000 curies for 1993. This represented a $20 \%$ increase over tritium release amounts in 1992. Annual tritium releases to the atmosphere over the past 10 years are given in Figure 1. Since 1985 tritium forms monitoring has enabled the Site to report release amounts for both oxide and elemental tritium releases. The larger oxide release in 1985 resulted from the leakage and evaporation of CReactor moderator.

Figure 2 presents the 1993 atmospheric tritium releases by facility and chemical form. The dose to the population exposed to atmospheric tritium is dependent upon the amount released as tritium oxide; tritium in the elemental form is biologically inactive. The separations facilities (all of F and HAreas) were responsible for $80 \%$ of atmospheric tritium releases and $71 \%$ of the tritium oxide released.

In $1993,16.9 \mathrm{mCi}$ of $\mathrm{C}-14$ were released from the separations facilities accounting for less than $0.1 \%$ of the atmospheric dose to the maximum individual. The ten-year trend of C-14 atmospheric releases from SRS is shown in Figure 3. The separations facility accounted for all of the C-14 released to the atmosphere in 1993. Reduced separations processing after 1989 has resulted in the reduction of C-14 releases to the atmosphere from the separations facilities.

The ten-year trend for I-129 atmospheric releases is given in Figure 4. Releases of 1-129 originate at the separations facilities and are independent of reactor status. The amount of 1-129 released to the atmosphere slightly increased from already low amounts in 1992 which can be accounted for in nominal release variability from year to year. Iodine-131 releases were very low during 1993.

Figure 5 shows that released amounts of $\mathrm{Sr}-90, \mathrm{Pu}-$ 238 and Pu-239 have slightly increased compared to 1992 releases More than $98 \%$ of the atmospheric $\mathrm{Pu}$ 239 releases were from the separations facilities. As noted in Table 2, unidentified alpha activity released to the atmosphere is assumed to be Pu-239 and unidentified beta is assumed to be Sr-90. These assumptions are made to ensure conservative dose estimates. Approximately $34 \%$ of the total Pu-239 and $75 \%$ of the total Sr-90 was unidentified alpha and beta-gamma, respectively.

Figure 6 shows the ten-year trend of short-lived noble gases (Kr-85 not included) released at the SRS. Since the release of these gases was entirely dependent upon reactor operations, no short-lived noble gases have been released since 1988 except when K Reactor was operational for a short time in 1992.

Sources of non-point radiological emissions to the atmosphere were included in the source term for the first time in 1991. This group includes seepage basins, burial grounds, open pits and tanks, etc. These sources are included in the annual NESHAP report and the Annual Environmental Report. As seen in Table 2, a few nuclides were included in the source term for non-point emissions only: Sr-35, Ni-63, Zr95, Sb-125, Ce-144, Eu-154, and Eu-155. Doses resulting from atmospheric releases were not significantly influenced by the addition of these non-point sources.

\section{LIQUID RELEASES}

Aqueous radioactive releases for 1993 are given in Table 3. Liquid discharge rates were generally lower than in 1992 except for Pm-147 and Cs-137. Tritum, Sr-90, Cs-137, and Pu-239 were responsible for more than $99 \%$ of the maximum individual and population doses from liquid releases.

In 1993, more than $85 \%$ of the total tritium reaching the Savannah River originated from seepage basin migration with the remainder coming from direct releases to onsite streams. The release values given in Table 3 and subsequent figures include tritium from both direct releases and seepage basin migration. The ten-year trend of tritium reaching the Savannah River is given in Figure 7. As seen in the figure, the release amount in 1993 was lower than in 1992. The increase in the curve during 1991 was due to the December release from a K-Reactor heat exchanger.

A 10-year trend of annual average tritium concentrations at various locations along the Savannah River is presented in Figure 8. Concentrations at sampling locations just below the Site (River 10) and 100 miles downstream, at Beaufort-Jasper and Port Wentworth were shown. The values presented for the BeaufortJasper and Port Wentworth areas are the concentrations measured in finished drinking water at each facility. Over the past 10 years, annual average tritium 
concentrations in the drinking water at Beaufort-Jasper and Port Wentworth have been less than $17 \%$ of the EPA guide for public drinking water supplies of $20 \mathrm{pCi} / \mathrm{ml}$. In 1993, tritium concentrations in the drinking water supplies were 5\% of the EPA guide.

Beaufort-Jasper and Port Wentworth are the only public water systems that draw water directly from the Savannah River at locations downstream of the SRS. River water in the Beaufort Jasper system is diluted by surface water flowing in the 18 mile canal connecting the river and the water treatment plant. River water entering the Port Wentworth system is diluted due to the close proximity of Abercom Creek to the intake point. In both cases, tritium measurements are used to correct for the actual dilution when dose calculations are made.

Aqueous release amounts of $\mathrm{Sr}-90, \mathrm{Cs}-137$, and $\mathrm{Pu}$ 239 are given in Figure 9 for the 10-year period, 1984 through 1993. Strontium-90 (including unidentified beta/gamma) releases, had a sharp decrease for the first time in four years due primarily to a reduction in reactor releases. Aqueous plutonium (including unidentified alpha) releases have essentially remained the same over the past several years. Figure 10 provides annual average Cs-137 concentrations in Savannah River water measured downstream of the SRS. The apparent peak of aqueous Cs-137 releases during 1987 and 1988 resulted from changes in analytical methods and detection sensitivities.

As shown in Figure 11A, in 1993,95\% of the Cs-137 releases were from the separations facilities with the remainder from reactors. As seen in Figures $11 B$ and $11 \mathrm{C}$, the dominant releases of aqueous $\mathrm{Sr}-90$ and $\mathrm{Pu}-$ 239 were from the reactors and separations facilities. Other facilities released only about $10 \%$ of the total Sr-90 and 4\% of the total Pu-239.

\section{ATMOSPHERIC DOSE}

Atmospheric dose estimates were calculated using derivatives of the NRC computer programs XOQDOQ (Baver, 1991) and GASPAR (Hamby, 1992). SRTC's versions of these amospheric transport and dosimetry codes, MAXIGASP and POPGASP (Hamby, 1991), provide dose predictions for an average individual, a maximum individual, and the population within $80 \mathrm{~km}$ of the geographic center of the SRS. Maximum individual offsite doses were calculated for hypothetical persons living at the site boundary for the entire year.

Average individual dose at the Savannah River Site showed a slight increase in 1993 due to an increase in the amount of tritium oxide released. Doses are given by pathway and radionuclide in Table 4 . The critical pathways through which the average individual $a$ the site boundary received the majority of dose were inhalation and the consumption of vegetation grown at the Site boundary. The nuclides of major importance were tritium, I-129, U-235/238, and Pu-238/239. The dose to the hypothetical average individual living at the site boundary from Site operations in 1993 was $0.051 \mathrm{mrem}$.

Table 5 presents the dose estimates for the maximum individual at the site boundary. The dose by pathway again shows that the inhalation pathway contributed more to total dose than the consumption of regetation. The milk pathway contributed about 9 percentage points more to maximum dose than it did to average dose. The nuclides of interest for the maximum individual were tritium, I-129, U-235/238, and Pu238/239. The maximum individual's dose resulting from the 1993 atmospheric releases was estimated to be 0.11 mrem, slightly higher than in 1992 .

The estimate of cumulative dose to the population within 50 miles of the SRS for 1993 is shown in Table 6. A breakdown of the estimate by pathway and nuclide is presented in the table and graphically in Figs. 12A and 12B. Again, the critical pathways for the population were inhalation and the consumption of vegetation. As expected, the critical nuclides are tritium, I-129, U-235/238, and Pu-238/239. The population dose from atmospheric releases in 1993 from SRS operations was estimated to be 7.6 person-rem.

The trends of average and maximum individual doses over the past 10 years are given in Figure 13. The dose estimates for 1993 were higher than the 1992 values. The ten-year trend of popalation doses is given in Figure 14. The data show that population doses have been steadily decreasing since 1987 until the slight increase in 1993 which would indicate variability from year to year.

Tables 7 and 8 provide breakdowns of maximum individual and population dose by nuclide and release facility. These tables are useful in determining relative and absolute contributions from facilities and/or nuclides to the offsite dose via atmospheric pathways. 
Isotopes are listed only if their contribution to the total dose is $>0.1 \%$. Tables $7 \& 8$ account for the isotopes contributing $>99 \%$ of the total dose.

\section{LIQUID DOSES}

The maximum individual dose was estimated for a hypothetical individual who drinks untreated river water, consumes large amounts of fish, and spends many hours swimming, fishing, and boating on the Savannah River. This dose was estimated using LADTAP II (Simpson, 1980), an NRC code for determining dose to man from liquid effluents. Table 9 gives the breakdown of the maximum individual's dose by pathway and radionuclide for liquid releases. Strontium-90 and Cs-137 accumulation in fish and tritium in river water used for consumption accounted for about $97 \%$ of the maximum individual's dose. The dose to the maximum individual resulting from aqueous releases during 1993 was $0.14 \mathrm{mrem}$.

Two changes were made in the 1993 calculation of dose to the maximum individual. 1) The fresh water shellfish pathway was eliminated after a survey indicated no known consumption of fresh water shellish (Hamby, 1994). 2) The maximum individual consumption of river water was changed from 1 liter per day to 2 liters per day to be consistent with calculations for water treatment plants. The net result was a $10 \%$ increase for the maximum individual dose.

The maximum dose to individuals consuming water processed by the Beaufort-Jasper and Port Wentworth water treatment facilities was calculated assuming a consumption rate of 2 liters per day. The maximum individual on these domestic water systems received doses of $0.038 \mathrm{mrem}$ (Beaufort-Jasper) and 0.051 mrem (Port Wentworth).

The population dose is calculated for several population groups. One group uses the Savannah River for recreational purposes, one group consumes sport and commencial fish and one group drinks treated river water from the Beaufort-Jasper or Port Wentworth public water systems. Table 10 presents the population dose to Savannah River users by pathway (population group) and by radionuclide. About $90 \%$ of the population dose can be attributed to the drinking water supplies at Beaufort-Jasper and Port Wentworth. Tritium, Sr-90, Cs-137 and Pu-239 were responsible for more than $99 \%$ of the population dose from aqueous releases. (For the purposes of conservatively estimating dose, all unidentified beta/gamma activity was assumed to be $\mathrm{SF} 90$ and all unidentified alpha activity was assumed to be Pu-239.) Tritium and $\mathrm{Pu}-239$ deliver the water ingestion dose while $\mathrm{Sr}$ 90 and $\mathrm{Cs}-137$ deliver the fish consumption dose. Figures $15 \mathrm{~A}$ and 15B show the pathway and nuclide breakdowns for the population dose The total population dose from liquid releases in 1993 was 1.5 person-rem.

Figures 16 and 17 present the ten-year trends of maximum individual and population dose estimates for liquid effluents to the Savannah River. The maximum individual dose trend shows a slight increase in the 1993 dose estimate from 1992. Population dose decreased in 1993 from already low levels in 1992, to reach a 10-year low.

Breakdowns of maximum individual and population dose by nuclide and facility are given in Tables 11 and 12 , respectively, for offsite doses via liquid pathways

\section{DOSE SUMMARY}

Dose estimates for both atmospheric and liquid releases over the past five years are summarized in Table 13. The maximum individual at the SRS boundary received a dose that was $22 \%$ and $7 \%$ higher than already negligibly low amounts in 1992 for atmospheric and liquid pathways, respectively. The total $80 \mathrm{~km}$ population dose resulting from atmospheric releases increased about 19\% from 1992. Liquid pathways resulted in a $41 \%$ decrease in population dose from 1992. The background doses to an average individual (about $300 \mathrm{mrem} / \mathrm{yr}$ ) and the 50 -mile and drinkingwater populations (approx. 200,000 person-rem/yr) from natural background are also given to show the relative impact of SRS operations on the surrounding environment. Maximum individual and population doses by release mode and facility, are summarized in Table 14. 


\section{REFERENCES}

Bauer 1991. Bauer, L.R., "Modeling Chronic Atmospheric Releases a the SRS: Evaluation and Verification of XOQDOQ", WSRC-RP-91-320, Westinghouse Savannah River Laboratory, Aiken, SC, 1991.

Carlton 1994. Cariton, W.H., "Environmental Dosimetry Data for 1993 Environmental Report (U)", WSRC Inter-Office Memorandum, SRT-ETS-940043, Westinghouse Savannah River Technology Center, Aiken, SC, 1994.

DOE 1990. Radiation Protection of the Public and Environment. DOE Order 5400.5, U.S. Department of Energy, February 8, 1990.

Hamby 1991. Hamby, D.M., “Environmental Dose Assessment Manual(U)”, WSRC Mamual, WSRC-IM-91-1, Westinghouse Savannah River Technology Center, Aiken, SC, 1991.

Hamby, 1992. Hamby, D.M., "Verification of the GASPAR Dose Assessment Module used in MAXIGASP and POPGASP", WSRC-RP-92-418, Westinghouse Savannah River Technology Center, Aiken, SC, 1992.

Hamby, 1994. Hamby, D.M., "Shellfishing in the Savannah River", SRT-ETS-940037, Westinghouse Savannah River Technology Center, Aiken, SC, 1994.

Simpson 1980. Simpson, D.B. and McGill, B.L., "User Manual for LADTAP II A Computer Program for Calculating Radiation Exposure to Man from Routine Release of Nuclear Reactor Liquid Effluents", NUREG/CR-1276, ORNL/NUREG/IDMC-1, Oak Ridge National Laboratory, Oak Ridge, TN, 1980. 
Table 2. 1993 Atmospheric Releases (curies)

Nuclide Reactors Sepns Reactor HeavyWater SRTC Non-point(a) Total

\section{GASES AND VAPORS}

$\begin{array}{lll}\text { H-3(oxide) } & 3.85 \times 10^{4} & 9.39 \times 10^{4} \\ \text { H-3(elem.) } & & 5.82 \times 10^{4} \\ \text { H-3(total) } & 3.85 \times 10^{4} & 1.52 \times 10^{5} \\ \text { C-14 } & & 1.69 \times 10^{-2} \\ \text { Xe-135 } & & \\ \text { I-129 } & & 4.96 \times 10^{-3} \\ \text { I-131 } & & 8.89 \times 10^{-5} \\ \text { I-133 } & & \end{array}$

$\begin{array}{cccc}4.48 \times 10^{2} & & 4.31 \times 10^{1} & 1.33 \times 10^{5} \\ & & & 5.82 \times 10^{4} \\ 4.48 \times 10^{2} & & 4.31 \times 10^{1} & 1.91 \times 10^{5} \\ & & 4.00 \times 10^{-6} & 1.69 \times 10^{-2} \\ & 3.19 \times 10^{-2} & & 3.19 \times 10^{-2} \\ & & 6.88 \times 10^{-7} & 4.96 \times 10^{-3} \\ & 5.92 \times 10^{-5} & & 1.48 \times 10^{-4} \\ & 1.96 \times 10^{-3} & & 1.96 \times 10^{-3}\end{array}$

\section{PARTICULATES}

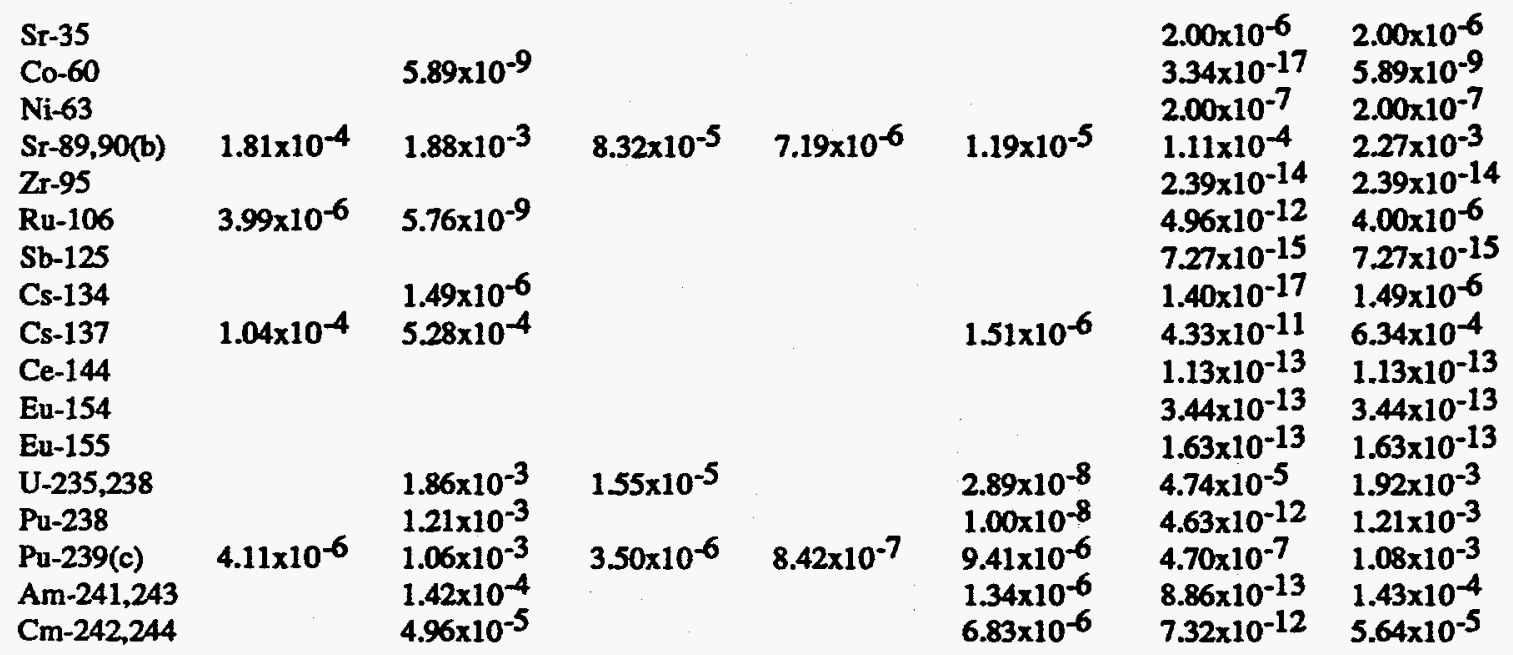

(a) Estimated releaves from minor unmonitored non-point sources such as seepage busins, burial grounds, open pits, tanks, and etc. (b) Includes uridentifiod bets-gamma.

(c) Includes unidentified elpha.

Table 3. 1993 Liquid Releases (curies)

\begin{tabular}{|c|c|c|c|c|c|c|}
\hline Nuclide & Reactors & Sepns & $\begin{array}{l}\text { Reactor } \\
\text { Materials }\end{array}$ & Heavy Water & SRTC & Total \\
\hline H-3(a) & $2.29 \times 10^{3}$ & $9.88 \times 10^{3}$ & & $4.99 \times 10^{2}$ & $1.29 \times 10^{-1}$ & $1.27 \times 10^{4}$ \\
\hline $\begin{array}{l}\text { Sr-90 (b) } \\
\text { I-129 }\end{array}$ & $1.87 \times 10^{-1}$ & $\begin{array}{l}2.41 \times 10^{-1} \\
2.20 \times 10^{-2}\end{array}$ & & $4.65 \times 10^{-2}$ & $2.02 \times 10^{-3}$ & $\begin{array}{l}4.77 \times 10^{-1} \\
2.20 \times 10^{-2}\end{array}$ \\
\hline Cs-137 & $1.29 \times 10^{-2}$ & $2.33 \times 10^{-1}$ & & & & $2.46 \times 10^{-1}$ \\
\hline Pm-147 & & $7.03 \times 10^{-3}$ & & & & $7.03 \times 10^{-3}$ \\
\hline U-235,238 & & $1.14 \times 10^{-5}$ & & & & $1.14 \times 10^{-5}$ \\
\hline $\mathrm{Pu}-239$ (c) & $5.97 \times 10^{-4}$ & $8.65 \times 10^{-3}$ & $7.64 \times 10^{-5}$ & & $2.66 \times 10^{-4}$ & $9.59 \times 10^{-3}$ \\
\hline
\end{tabular}

(a) Includes diroct relouses and secpage basin migntion.

(b) Includes unidentified beta-gamms

(c) Includes unidentified aliph. 
Table 4. Average Individual Dose at Site Boundary from Atmospheric Releases

\section{BY PATHWAY}

Inhalation

Vegetation

Milk

Meat

Plume

Ground

Total

\section{BY RADIONUCLIDE}

Gases \& Vapors

H-3

C-14

I-129

I-131

I-133

Particulates
Average Individual

Dose (mrem)

$3.1 \times 10^{-2}$

$1.3 \times 10^{-2}$

$4.2 \times 10^{-3}$

$1.8 \times 10^{-3}$

$3.0 \times 10^{-8}$

$1.0 \times 10^{-4}$

$5.1 \times 10^{-2}$

Average Individual

Dose (mrem)

$4.5 \times 10^{-2}$

$1.8 \times 10^{-6}$

$1.0 \times 10^{-3}$

$7.5 \times 10^{-7}$

$3.6 \times 10^{-7}$

$5.3 \times 10^{-5}$

$4.0 \times 10^{-8}$

$4.1 \times 10^{-5}$

$6.0 \times 10^{-4}$

$1.7 \times 10^{-3}$

$1.7 \times 10^{-3}$

$2.3 \times 10^{-4}$

$6.3 \times 10^{-5}$

$5.1 \times 10^{-2}$
Percent of

Total Dose

61.5

26.5

8.3

3.5

$<0.1$

0.2

Percent of Total Dose
89.4

$<0.1$

2.0

$<0.1$

$<0.1$

Total

0.1

$<0.1$

0.1

1.2

3.3

3.4

0.5

0.1

a. Avenge of all dose catimates caleulated at the site perimeter. Individual conames merage amounts of food (includes cow's milk). Committed effective dowe equivalent is repated. 
Table 5. Maximum Individual Dose ${ }^{a}$ at Plant Perimeter from Atmospheric Releases

\section{BY PATHWAY}

Inhalation

Vegetation

Milk

Meat

Plume

Ground

Total

BY RADIONUCLIDE

Gases \& Vapors

H-3

C-14

I-129

I-131

I-133

Particulates
ST-90
Ru-106
Cs-134,137
U-235,238
$\mathrm{Pu}-238$
Pu-239
Am-241,243
Cm-242,244
Total

Maximum Individual

Dose (mrem)

$5.1 \times 10^{-2}$

$3.8 \times 10^{-2}$

$1.3 \times 10^{-2}$

$5.5 \times 10^{-3}$

$1.6 \times 10^{-7}$

$1.7 \times 10^{-4}$

$1.1 \times 10^{-1}$

Maximum Individual

Dose (mrem)

$9.6 \times 10^{-2}$

$5.4 \times 10^{-6}$

$2.7 \times 10^{-3}$

$4.5 \times 10^{-6}$

$2.2 \times 10^{-6}$

$1.7 \times 10^{-4}$

$1.0 \times 10^{-7}$

$7.1 \times 10^{-5}$

$1.1 \times 10^{-3}$

$3.3 \times 10^{-3}$

$3.8 \times 10^{-3}$

$5.0 \times 10^{-4}$

$2.1 \times 10^{-4}$

$1.1 \times 10^{-1}$
Percent of

Total Dose

47.4

35.2

12.2

5.1

$<0.1$

0.2

Percent of

Total Dose

89.4

$<0.1$

2.5

$<0.1$

$<0.1$

*Individual rexides at the site boundary and conames maximum ancuns of food. Committed effective dose equivalent is reparted. 
Table 6. 80-Kilometer Population Dose at Plant Perimeter from Atmospheric Releases

\section{BY PATHWAY}

Inhalation

Vegetation

Milk

Meat

Ground

Plume

Total

BY RADIONUCLIDE

Gases \& Vapors

H-3

C-14

I-129

I-131

I-133

Particulates

Sr-90

Ru-106

Cs-134,137

U-235,238

Pu-238

Pu-239

Am-241,243

Cm-242,244

Total
Population Dose

(Person-rem)

$5.8 \times 10^{0}$

$1.1 \times 10^{0}$

$5.8 \times 10^{-1}$

$1.5 \times 10^{-1}$

$2.7 \times 10^{-2}$

$7.4 \times 10^{-7}$

$7.6 \times 10^{0}$

Population Dose

(Person-rem)

$6.9 \times 10^{0}$

$1.8 \times 10^{-4}$

$9.3 \times 10^{-2}$

$5.0 \times 10^{-5}$

$5.1 \times 10^{-6}$

$4.2 \times 10^{-3}$

$3.6 \times 10^{-6}$

$6.9 \times 10^{-3}$

$9.6 \times 10^{-2}$

$2.3 \times 10^{-1}$

$2.3 \times 10^{-1}$

$3.1 \times 10^{-2}$

$6.3 \times 10^{-3}$

$7.6 \times 10^{0}$
Percent of

Total Dose

75.4

14.7

7.7

1.9

0.3

$<0.1$

Percent of

Total Dose

91.0

$<0.1$

1.2

$<0.1$

$<0.1$

0.1

$<0.1$

0.1

1.3

3.0

3.0

0.4

0.1

2. Commined effective dose equivalent is reported (coms mill). 
Table 7. Maximum Individual Dose (mrem) from Atmospheric Releases*

\begin{tabular}{|c|c|c|c|c|c|c|c|c|}
\hline \multirow{2}{*}{\multicolumn{2}{|c|}{$\begin{array}{l}\text { Nuclide Reactors } \\
\text { H-3 (oxide)2.8E-02 }\end{array}$}} & \multirow{2}{*}{$\begin{array}{l}\text { Sepns } \\
6.8 \mathrm{E}-02\end{array}$} & \multirow{2}{*}{$\begin{array}{l}\text { Reactor } \\
\text { Materials }\end{array}$} & \multirow{2}{*}{$\begin{array}{l}\text { Heavy } \\
\text { Water } \\
2.3 E-04\end{array}$} & \multirow[t]{2}{*}{ SRTC } & \multicolumn{2}{|c|}{ Non-pointTotal } & \multirow{2}{*}{$\begin{array}{l}\text { \% of } \\
\text { Total } \\
89.0\end{array}$} \\
\hline & & & & & & $2.2 \mathrm{E}-05$ & $9.6 \mathrm{E}-02$ & \\
\hline Sr-90 & $1.3 \mathrm{E}-05$ & $1.4 \mathrm{E}-04$ & 6.1E-06 & $5.3 E-07$ & 8.8E-07 & 8.2E-06 & $1.7 \mathrm{E}-04$ & 0.2 \\
\hline I-129 & & 2.7E-03 & & & & 3.8E-07 & 2.7E-03 & \\
\hline U-235,238 & $1.1 \mathrm{E}-03$ & $8.9 \mathrm{E}-06$ & & $1.78 \mathrm{E}-08$ & $2.7 \mathrm{E}-05$ & 1.1E-03 & 1.0 & \\
\hline Pu-238 & & $3.3 E-03$ & & & 2.7E-08 & $1.3 \mathrm{E}-11$ & 3.3E-03 & 3.1 \\
\hline Pu-239 & $1.4 \mathrm{E}-05$ & 3.7E-03 & & $2.9 \mathrm{E}-06$ & $3.3 \mathrm{E}-05$ & $1.6 \mathrm{E}-06$ & 3.8E-03 & \\
\hline Am-241,2 & & 4.9E-04 & & & 4.7E-06 & $3.1 \mathrm{E}-12$ & $5.0 \mathrm{E}-04$ & \\
\hline $\mathrm{Cm}-242,2$ & & $1.9 \mathrm{E}-04$ & & & $2.6 \mathrm{E}-05$ & $2.7 \mathrm{E}-11$ & 2.1E-04 & \\
\hline Dose Total & 2.8E-02 & 8.0E-02 & $1.5 \mathrm{E}-05$ & 2.3E-04 & $6.8 \mathrm{E}-05$ & $5.9 \mathrm{E}-05$ & 1.1E-01 & \\
\hline$\%$ of Total & 25.8 & 73.7 & $<0.1$ & 0.2 & $<0.1$ & $<0.1$ & & \\
\hline
\end{tabular}

* Isotopes are conly shom if their contribution to total dose is $>0.1 \%$, therefore, percent totals may not equal 100.

Table 8. Population Dose (person-rem) from Atmospheric Releases

$\begin{array}{lllllllll}\text { Nuclide } & \text { Reactors } & \text { Sepns } & \begin{array}{l}\text { Reactor } \\ \text { Materials }\end{array} & \begin{array}{l}\text { Heavy } \\ \text { Water }\end{array} & \text { SRTC } & \text { Non-point } & \text { Total } & \begin{array}{r}\text { \% of } \\ \text { Total }\end{array} \\ \text { H-3 (oxide) } & 2.0 \mathrm{E}+00 & 4.9 \mathrm{E}+00 & & 2.3 \mathrm{E}-02 & & 2.3 \mathrm{E}-03 & 6.9 \mathrm{E}+00 & 91.0 \\ \mathrm{I}-129 & & 9.3 \mathrm{E}-02 & & & & 1.3 \mathrm{E}-05 & 9.3 \mathrm{E}-02 & 1.2 \\ \text { U-235,238 } & 9.3 \mathrm{E}-02 & 8.9 \mathrm{E}-04 & & 1.4 \mathrm{E}-06 & 2.4 \mathrm{E}-03 & 9.6 \mathrm{E}-02 & 1.3 \\ \text { Pu-238 } & 2.3 \mathrm{E}-01 & & & 1.9 \mathrm{E}-06 & 8.7 \mathrm{E}-10 & 2.3 \mathrm{E}-01 & 3.0 \\ \text { Pu-239 } & 8.6 \mathrm{E}-04 & 2.3 \mathrm{E}-01 & & 1.8 \mathrm{E}-04 & 2.0 \mathrm{E}-03 & 9.9 \mathrm{E}-05 & 2.3 \mathrm{E}-01 & 3.0 \\ \text { Am-241,243 } & 3.1 \mathrm{E}-02 & & & 2.9 \mathrm{E}-04 & 1.9 \mathrm{E}-10 & 3.1 \mathrm{E}-02 & 0.4 \\ \text { Dose Total } 2.0 \mathrm{E}-00 & 5.6 \mathrm{E}-00 & 9.3 \mathrm{E}-04 & 2.4 \mathrm{E}-02 & 3.1 \mathrm{E}-03 & 4.9 \mathrm{E}-03 & 7.6 \mathrm{E}-00 & \\ \text { \% of Total } 26.4 & 73.2 & <0.1 & 0.3 & <0.1 & <0.1 & & \end{array}$

- Isctopes are colly shown if their contribution to total dose is $>0.1 \%$, therefore, percent totals may not equal 100 . 
Table 9. Maximum Individual Dosea from Liquid Releases

\section{BY PATHWAY}

Fish Consumption

Drinking Water

Shoreline Activities

Boating

Swimming

Total

BY RADIONUCLIDE

H-3

Sr-90

I- 129

Cs-137

$\mathrm{Pm}-147$

$\mathrm{U}-235,238$

Pu-239

Total
Maximum Individual

Dose (mrem)

$7.8 \times 10^{-2}$

$6.6 \times 10^{-2}$

$2.5 \times 10^{-4}$

$1.9 \times 10^{-7}$

$1.6 \times 10^{-7}$

$1.4 \times 10^{-1}$

Maximum Individual

Dose (mrem)

$5.8 \times 10^{-2}$

$7.9 \times 10^{-3}$

$6.1 \times 10^{-4}$

$7.4 \times 10^{-2}$

$7.8 \times 10^{-7}$

$2.1 \times 10^{-7}$

$3.2 \times 10^{-3}$

$1.4 \times 10^{-1}$
Percent of

Total Dose

54.1

45.7

0.2

$<0.1$

$<0.1$

Percent of

Total Dose

40.5

5.5

0.4

51.0

$<0.1$

$<0.1$

2.2

2. Hypothetical person juc downtream of SRS. There are no known persons who meet the hypothetical simation. Commined effective dose equivalent is presented.

Table 10. Population Dose $e^{a}$ from Liquid Releases

\section{BY PATHWAY}

Beaufort-Jasper Water

Port Wentworth Water

Fish Consumption*

Recreation

Total

BY RADIONUCLIDE

H-3

ST-90

I-129

Cs-137

Pm-147

U-235,238

Pu-239

Total
Population Dose

(Person-rem)

$9.6 \times 10^{-1}$

$3.9 \times 10^{-1}$

$1.4 \times 10^{-1}$

$1.0 \times 10^{-2}$

$1.5 \times 10^{0}$

Population Dose

(Person-rem)

$1.1 \times 10^{0}$

$6.3 \times 10^{-3}$

$3.6 \times 10^{-4}$

$1.4 \times 10^{-1}$

$6.5 \times 10^{-7}$

$1.8 \times 10^{-7}$

$2.2 \times 10^{-1}$

$1.5 \times 10^{0}$
Percent of

Total Dose

63.8

26.0

9.5

0.7

Percent of Total Dose

75.5

0.4

$<0.1$

9.5

$<0.1$

$<0.1$

14.5

- inchudes aport and conumerrial firh and ealt wher vertebrates.

2. Committed effective dowe equivilent. 
Table 11. Maximum Individual Dose (mrem) from Liquid Releases

\begin{tabular}{|c|c|c|c|c|c|c|c|}
\hline Nuclide & Reactors & Sepns & $\begin{array}{l}\text { Reactor } \\
\text { Materials }\end{array}$ & $\begin{array}{l}\text { Heavy } \\
\text { Water }\end{array}$ & SRTC & Total & $\%$ of Total \\
\hline H-3 & $1.1 \mathrm{E}-02$ & 4.5E-02 & & 2.3E-03 & $5.9 \mathrm{E}-07$ & $5.8 \mathrm{E}-02$ & 40.5 \\
\hline Sr-90 & $3.1 E-03$ & 4.0E-03 & & 7.7E-04 & 3.3E-05 & 7.9E-03 & 5.5 \\
\hline I-129 & & $6.1 \mathrm{E}-04$ & & & & 6.1E-04 & 0.4 \\
\hline Cs-137 & $3.9 \mathrm{E}-03$ & $7.0 \mathrm{E}-02$ & & & & 7.4E-02 & 51.0 \\
\hline Pu-239 & $2.0 \mathrm{E}-04$ & $2.9 \mathrm{E}-03$ & $2.5 \mathrm{E}-05$ & & $8.9 \mathrm{E}-05$ & $3.2 \mathrm{E}-03$ & 2.2 \\
\hline Dose Total & $1.8 \mathrm{E}-02$ & $1.2 E-01$ & $2.5 \mathrm{E}-05$ & 3.1E-03 & $1.2 \mathrm{E}-04$ & $1.4 \mathrm{E}-01$ & \\
\hline$\%$ of Total & 12.3 & 85.4 & $<0.1$ & 2.1 & $<0.1$ & & \\
\hline
\end{tabular}

Table 12. Population Dose (person-rem) from Liquid Releases

\begin{tabular}{|c|c|c|c|c|c|c|c|}
\hline Nuclide & Reactors & Sepns & $\begin{array}{l}\text { Reactor } \\
\text { Materials }\end{array}$ & $\begin{array}{l}\text { Heavy } \\
\text { Water }\end{array}$ & SRTC & Total & \%o of Total \\
\hline $\mathrm{H}-3$ & $2.0 \mathrm{E}-01$ & $8.8 \mathrm{E}-01$ & & 4.4E-02 & 1.1E-05 & $1.1 E-00$ & 75.5 \\
\hline Sr-90 & $2.5 \mathrm{E}-03$ & $3.2 \mathrm{E}-03$ & & $6.2 \mathrm{E}-04$ & 2.7E-05 & $6.3 E-03$ & 0.4 \\
\hline $\begin{array}{l}\text { Cs-137 } \\
\text { Pu-239 }\end{array}$ & $\begin{array}{l}7.5 \mathrm{E}-03 \\
1.4 \mathrm{E}-02\end{array}$ & $\begin{array}{l}1.4 \mathrm{E}-01 \\
2.0 \mathrm{E}-01\end{array}$ & $1.7 \mathrm{E}-03$ & & $6.0 \mathrm{E}-03$ & $\begin{array}{l}1.4 \mathrm{E}-01 \\
2.2 \mathrm{E}-01\end{array}$ & $\begin{array}{l}9.5 \\
14.5\end{array}$ \\
\hline Dose Total & $2.3 \mathrm{E}-01$ & $1.2 \mathrm{E}+00$ & 1.7E-03 & 4.5E-02 & $6.1 \mathrm{E}-03$ & $1.5 E+00$ & \\
\hline$\%$ of Total & 15.3 & 81.2 & 0.1 & 3.0 & 0.4 & & \\
\hline
\end{tabular}


Table 13. 1989 Through 1993 Adult Offsite Doses

\begin{tabular}{|c|c|c|c|c|c|}
\hline Atmospheric Releases & 1989 & 1990 & 1991 & $1992 \dagger$ & 1993 \\
\hline Avg. Individual (mem) & 0.16 & 0.075 & 0.056 & 0.040 & 0.051 \\
\hline Max. Individual (mrem)* & 0.31 & 0.16 & 0.12 & 0.09 & 0.11 \\
\hline 80-km Population (per-rem) & 17 & 9.6 & 7.1 & 6.4 & 7.6 \\
\hline \multicolumn{6}{|l|}{ Liquid Releases } \\
\hline Max. Individual (mrem) & 0.30 & 0.17 & 0.34 & 0.13 & 0.14 \\
\hline Max. Ind. BJ (mrem) & 0.12 & 0.061 & 0.081 & 0.070 & 0.038 \\
\hline Max. Ind. PW (mrem) & 0.12 & 0.074 & 0.099 & 0.087 & 0.051 \\
\hline Population (person-rem)a & 0.62 & 0.21 & 0.42 & 0.11 & 0.15 \\
\hline Beaufort-Jasper Pop (per-rem) & 3.0 & 1.5 & 2.1 & 1.8 & 0.96 \\
\hline Port Wentworth Pop (per-rem) & 1.2 & 0.56 & 0.75 & 0.66 & 0.39 \\
\hline Total Population (per-rem) & 4.8 & 2.4 & 3.2 & 2.5 & 1.5 \\
\hline
\end{tabular}

\section{Background}

Individual

300 mrem

Population

$(685,000 \text { persons })^{b}$

200,000 person-rem

theginning in 1992, population data from the 1990 cenms ved for population dose.

a. includes the consumption of sport and commercial fish, salt water invertebrates, and recreational activities on the Savannah River.

b. 1990 cenaus, 80-bm population plus water consumess at Beanfort-Juper and Port Wentworth. 


\section{Table 14. Summary of Maximum Individual and Population Dose for 1993}

\begin{tabular}{lllll} 
Source & \multicolumn{2}{l}{ Maximum Individual(a) } & Population(b) \\
Reactors & Dose (mrem) & \% of Total & Dose (person-rem) & \% of Total \\
atmospheric & 0.028 & 11.2 & 2.0 & 22.0 \\
liquid & 0.018 & 7.2 & 0.23 & 2.5
\end{tabular}

\section{Separations}

atmospheric

liquid
0.08

0.12

32.0

48.0
5.6

1.2
61.5

13.2

HW, RM \& SRTC(c)

atmospheric

liquid

0.00037

0.0032

0.25

Total
0.2

1.3
0.033

0.053
0.3

0.5

9.1

(a) The maximum individual from liquid and amosheric releases is not the sume person, done extimates from both release modes are added hero caly to obtain an abeolure maximum dose.

(b) atmospheric dose to the 80-km populntion and liquid dose to Savanneh River water usen.

(c) HW - beavy water, RM - reactor materiais (also includes sito-wide Non-point ecurcen). 
Figure 1. 10-Year History of Atmospheric Tritium Releases

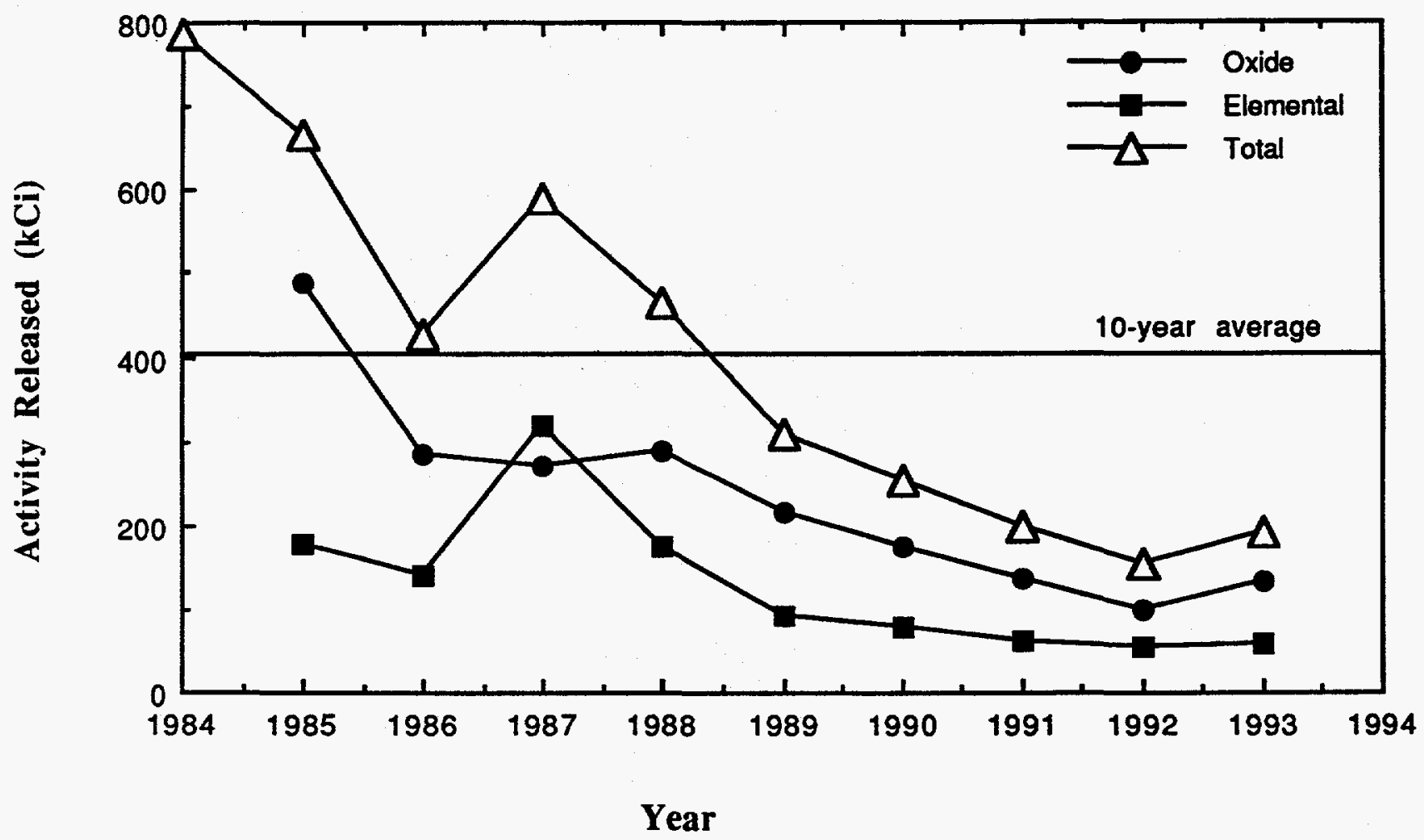


Figure 2. Relative Contribution to Atmospheric Tritium by Facility and Chemical Form

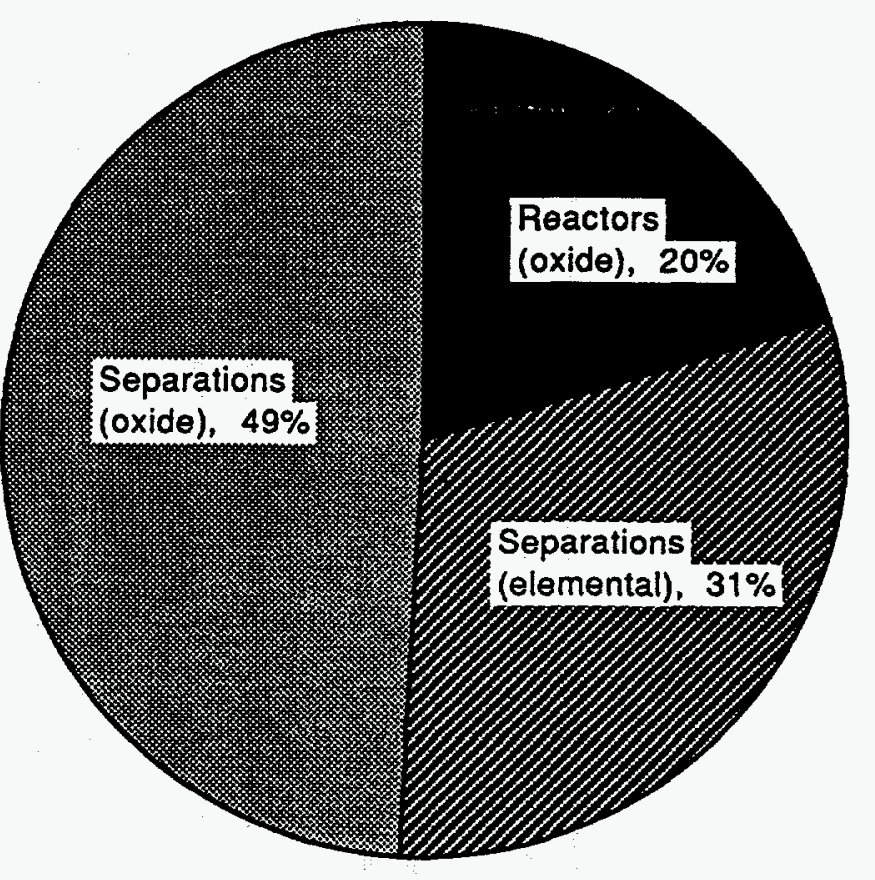


Figure 3. 10-Year History of Atmospheric C-14 Releases

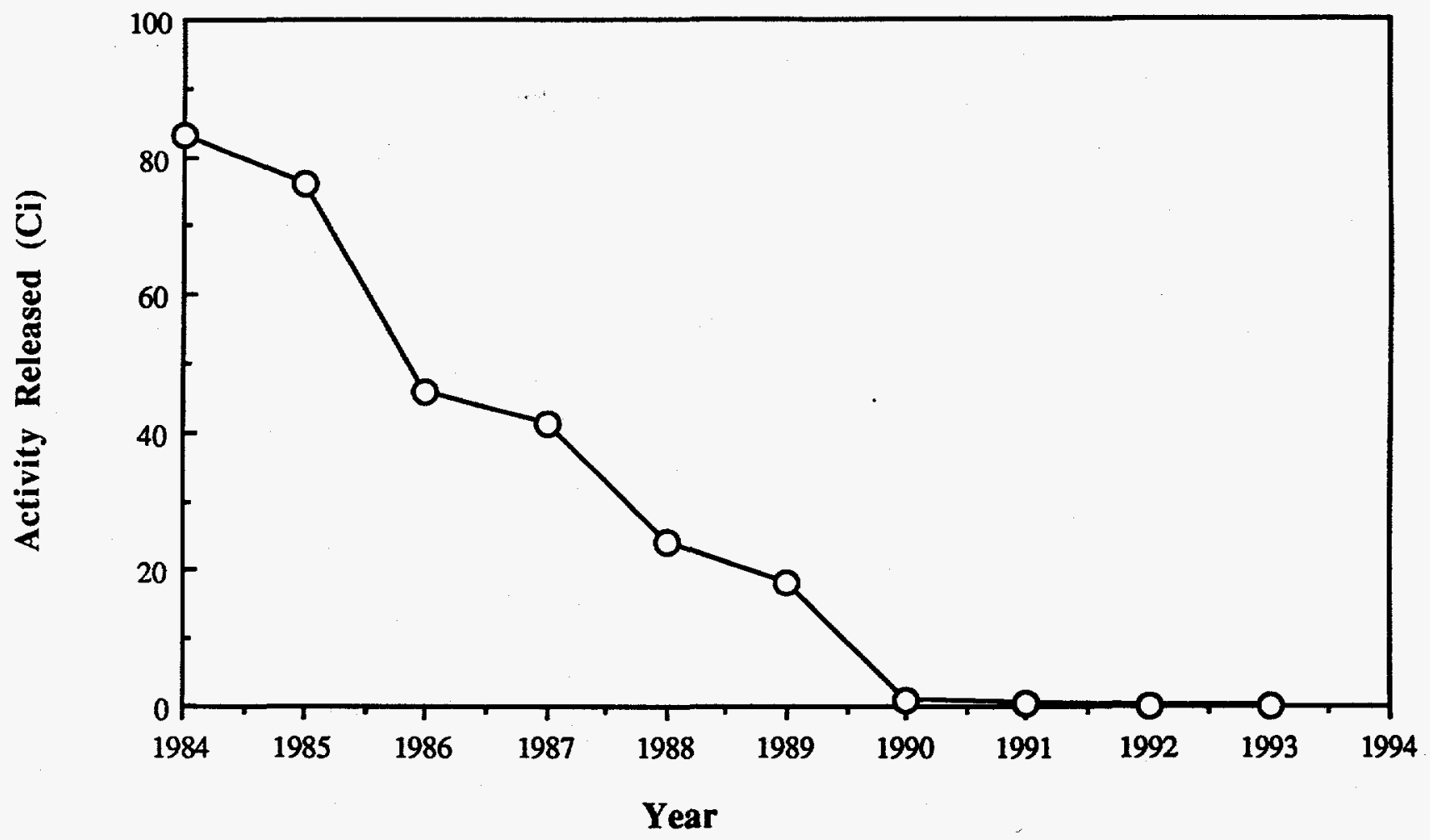


Figure 4. 10-Year History of Atmospheric I-129 Releases

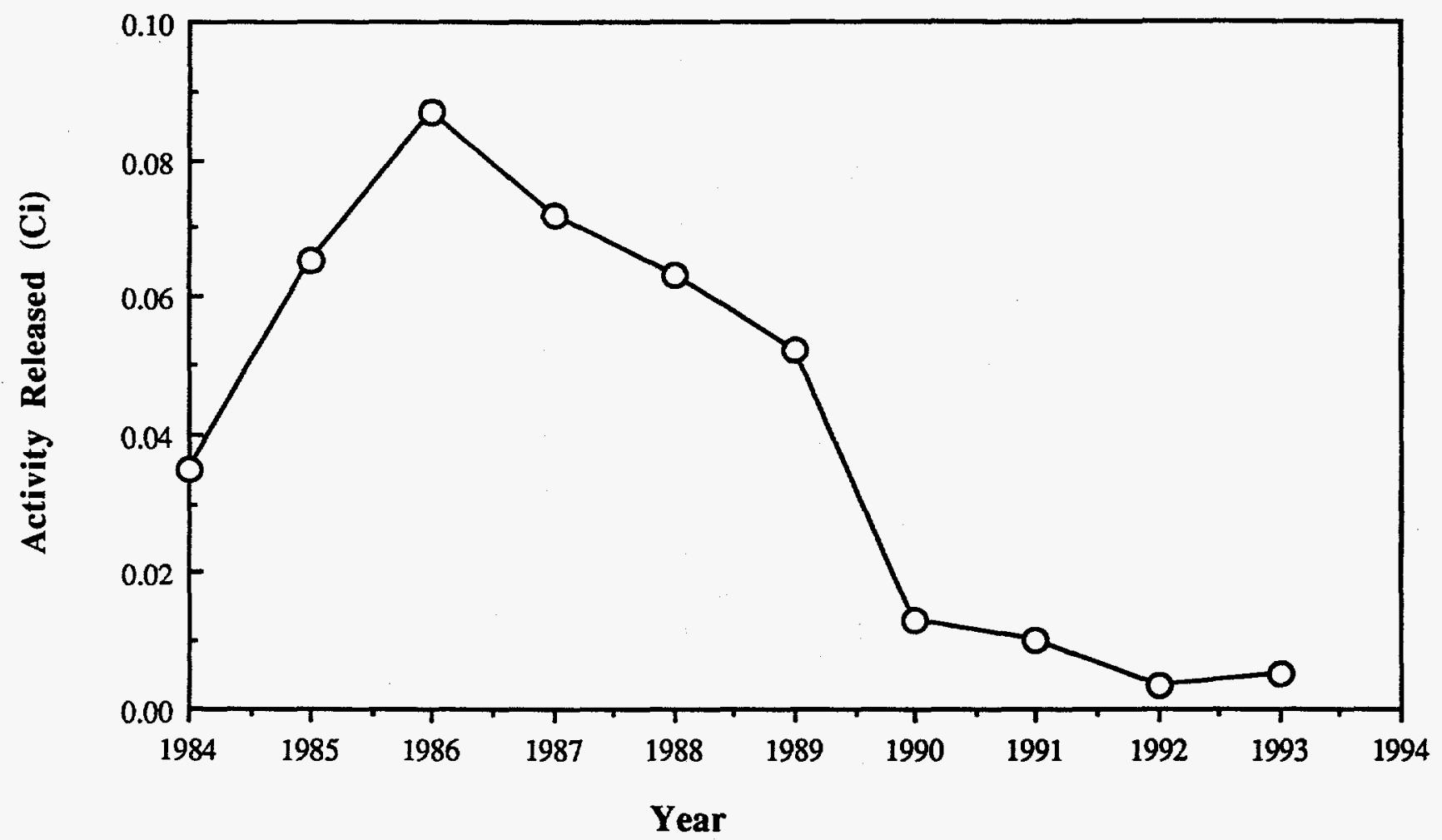


Figure 5. 10-Year History of Atmospheric Sr-90, Pu-238, and Pu-239 Releases

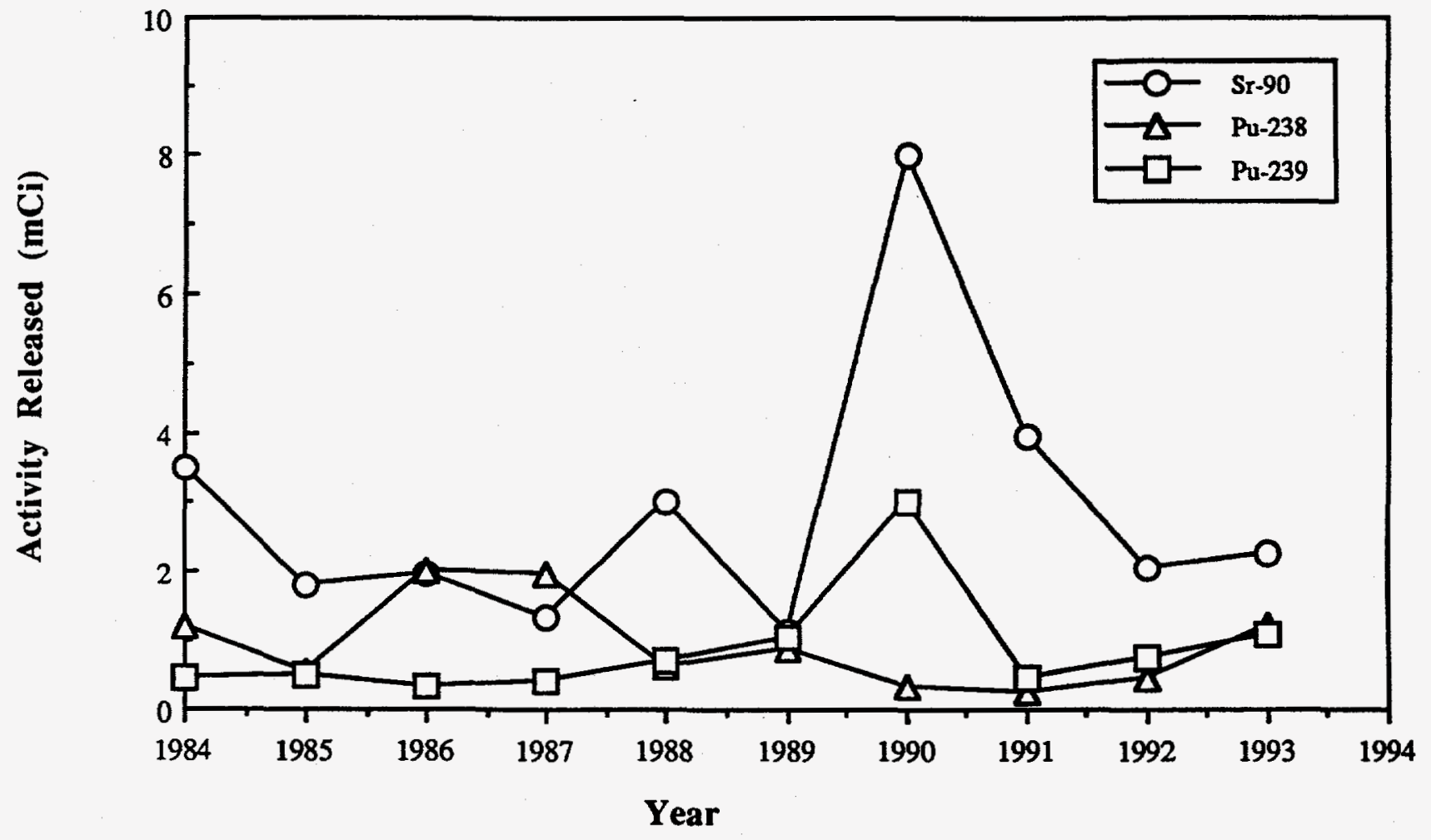


Figure 6. 10-Year History of Atmospheric Noble Gas Release

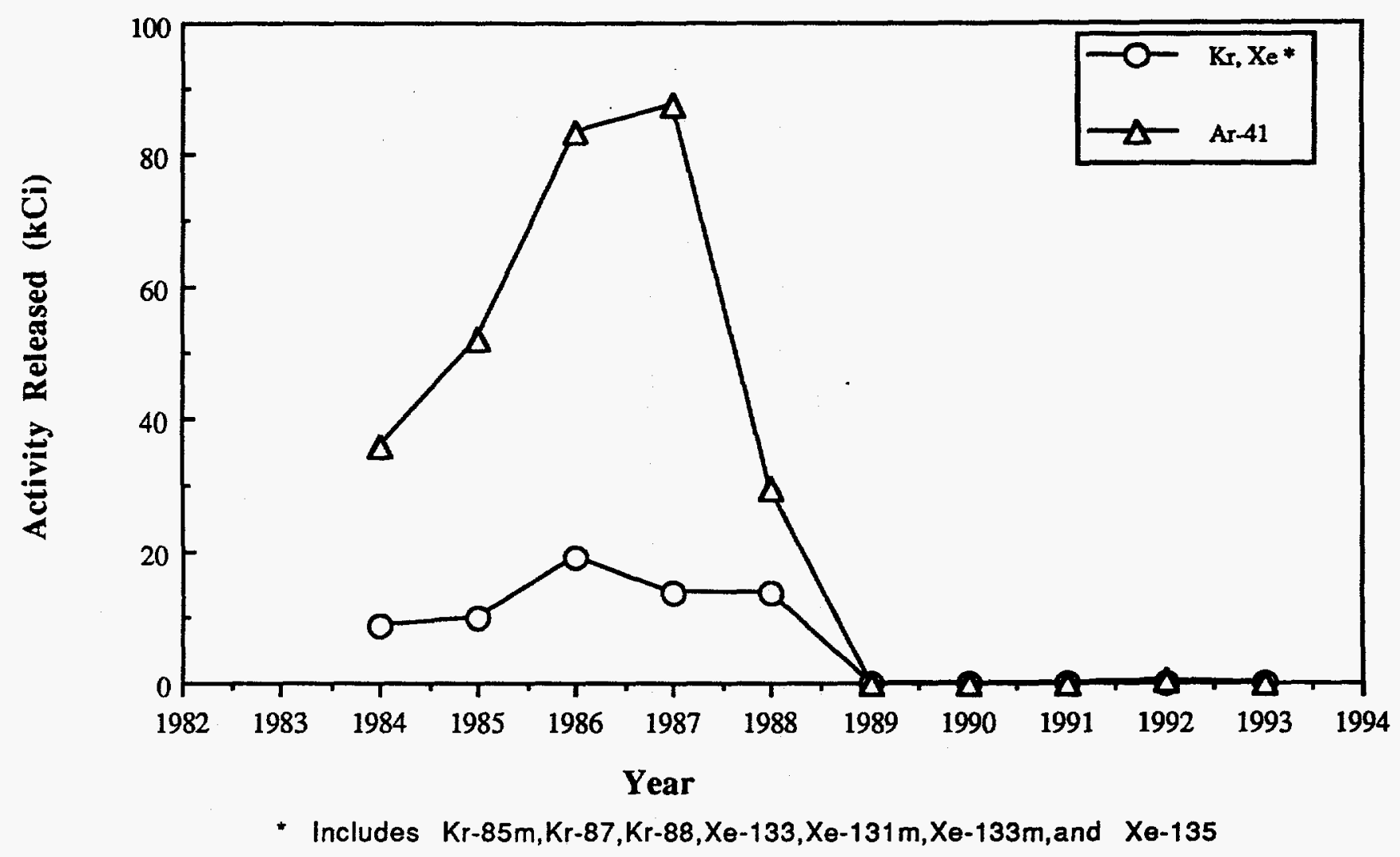


Figure 7. 10-Year History of Aqueous Tritium Releases.

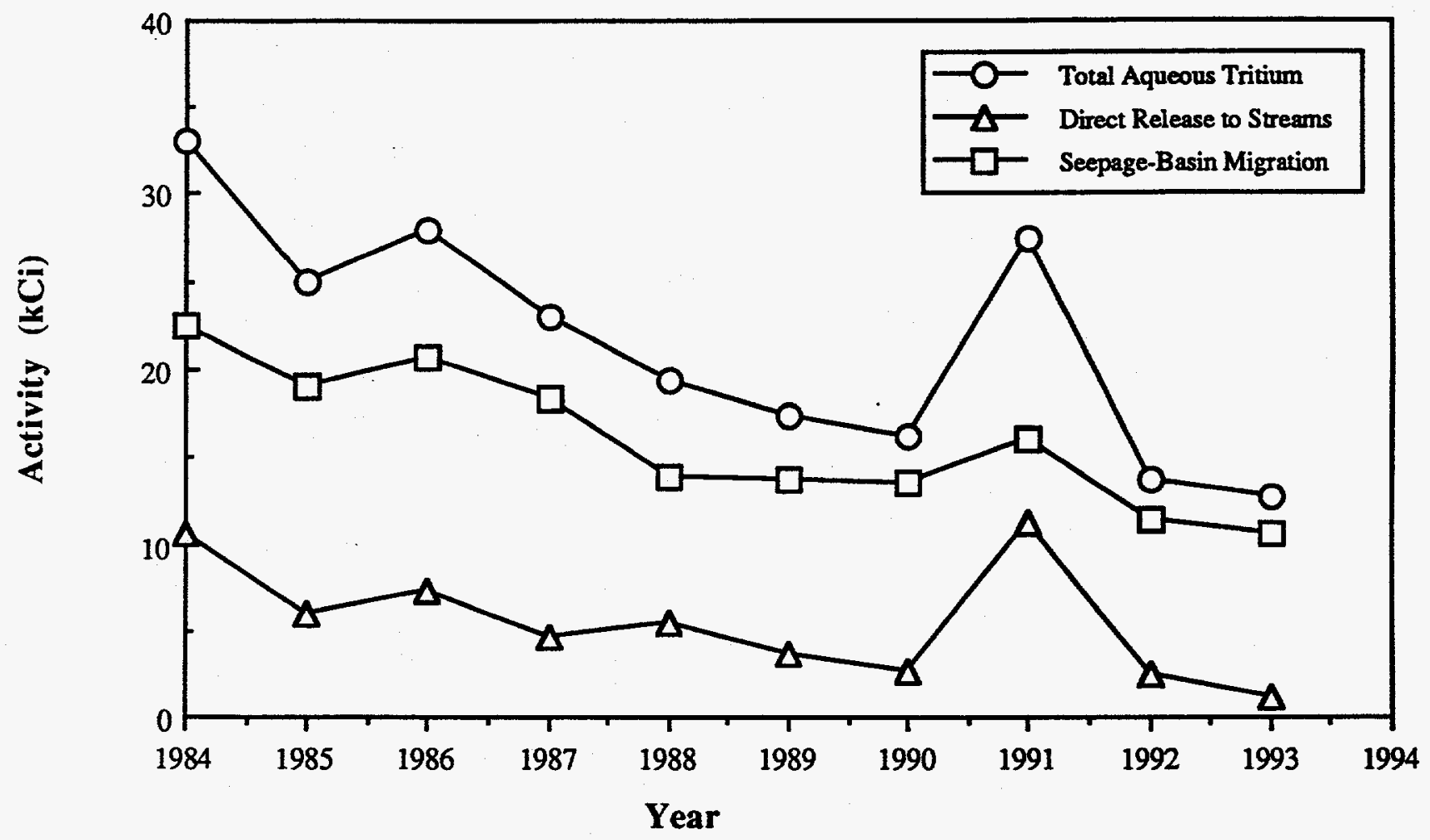


Figure 8. Tritium Concentrations in the Savannah River

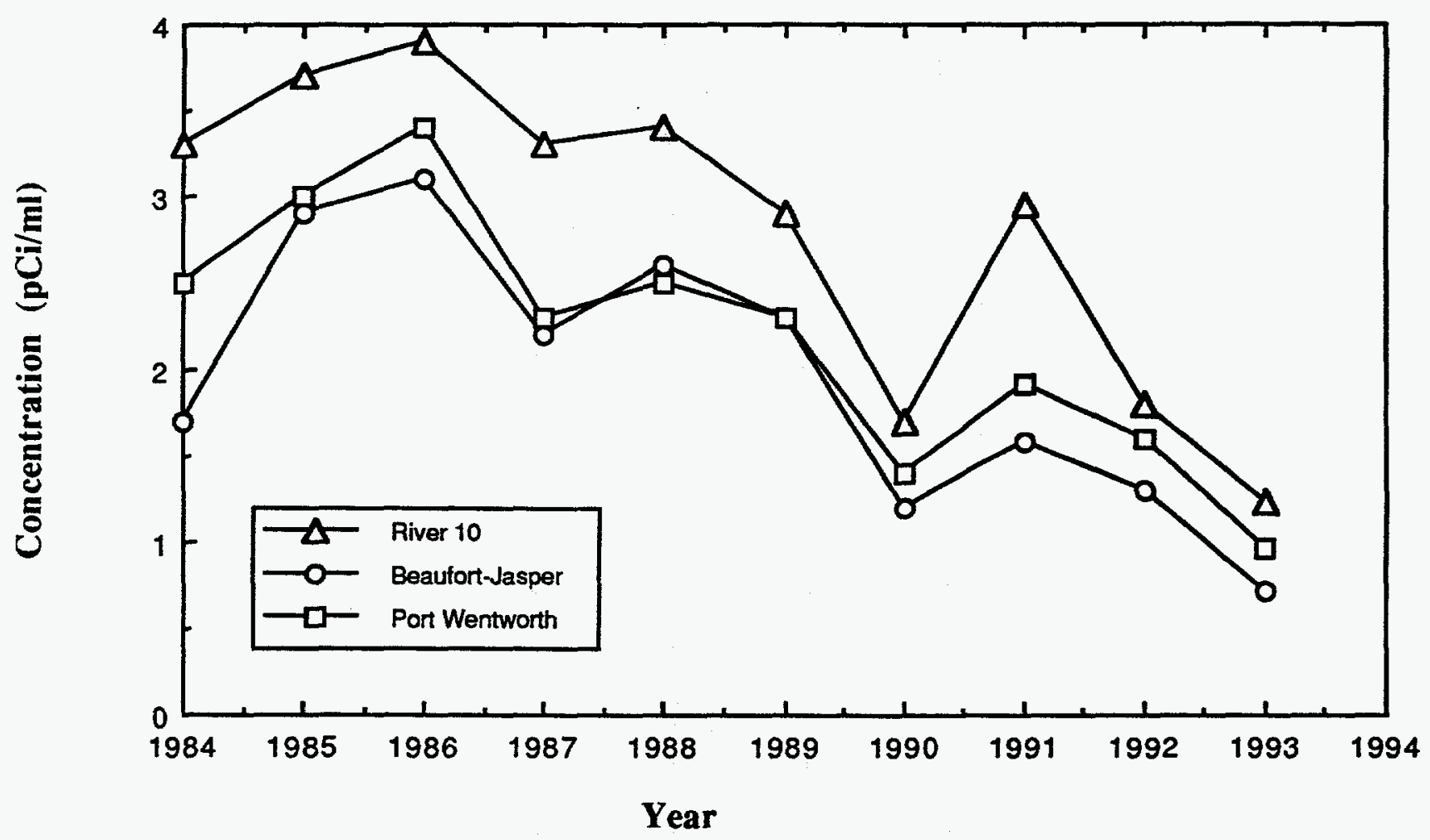


Figure 9. 10-Year History of Aqueous Sr-90, Cs-137, and Pu-239 Releases

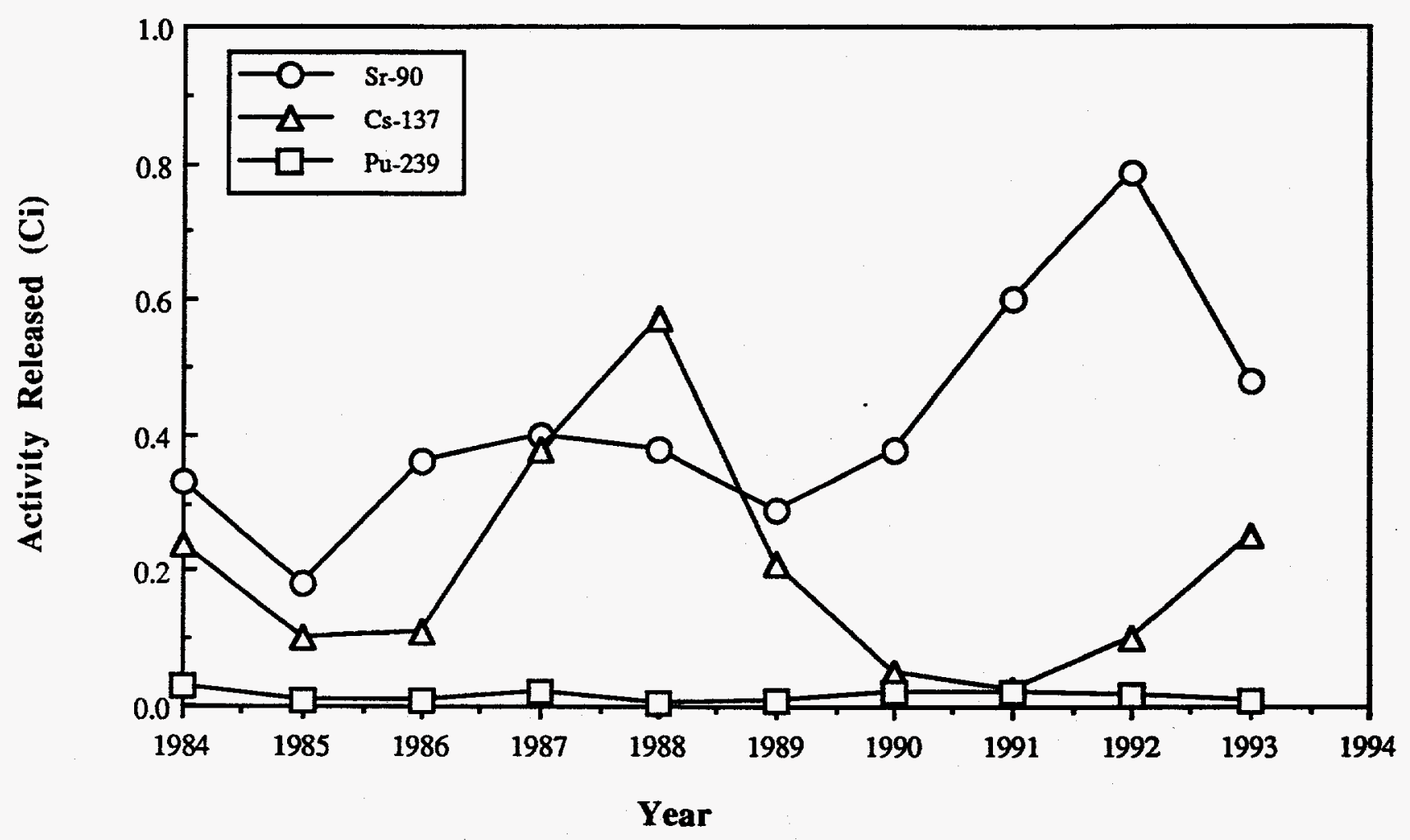


Figure 10. Cs-137 Concentrations in the

Savannah River (River 10)

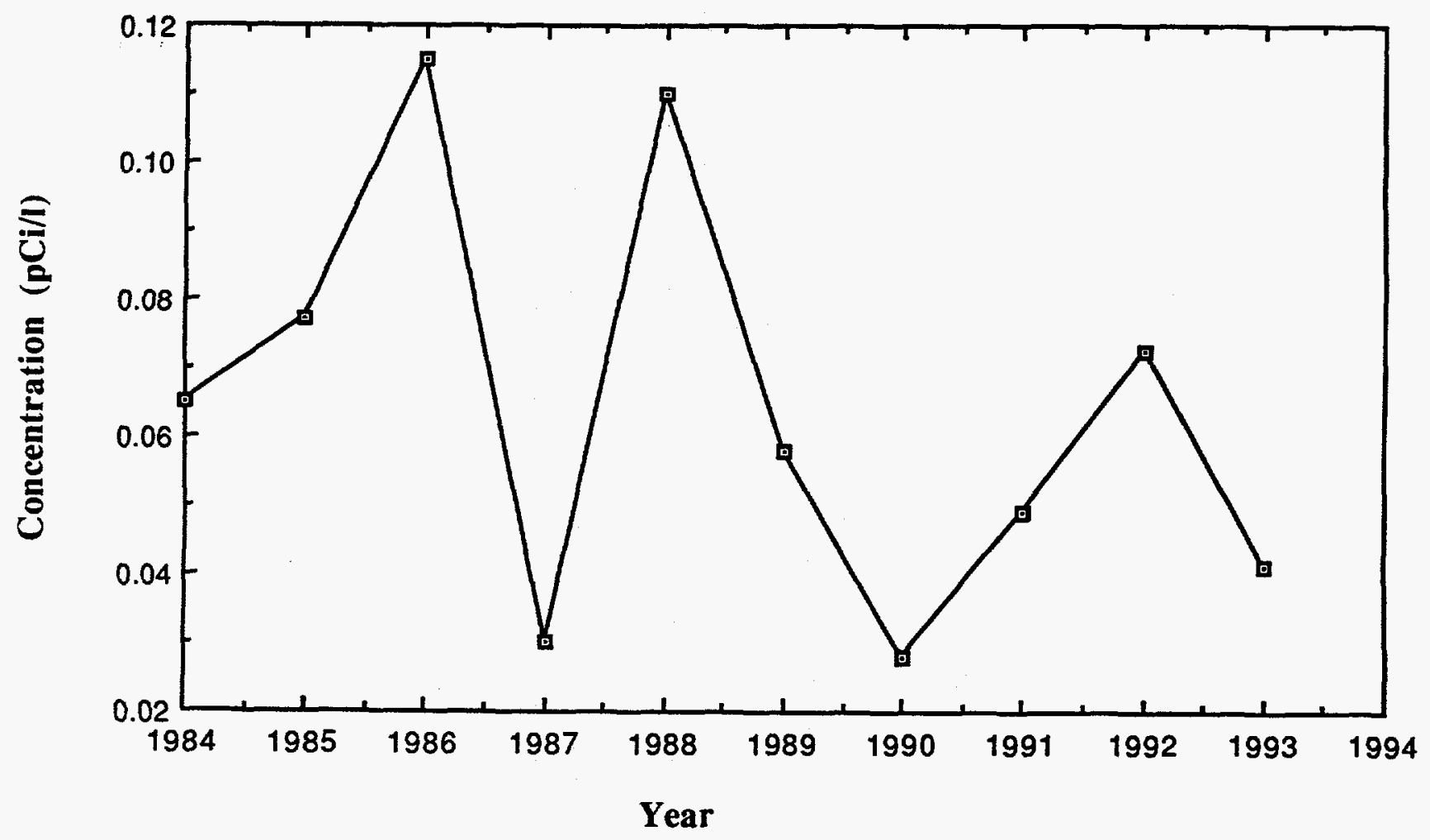


Figure 11A. Aqueous Release by Facility (Cs-137)

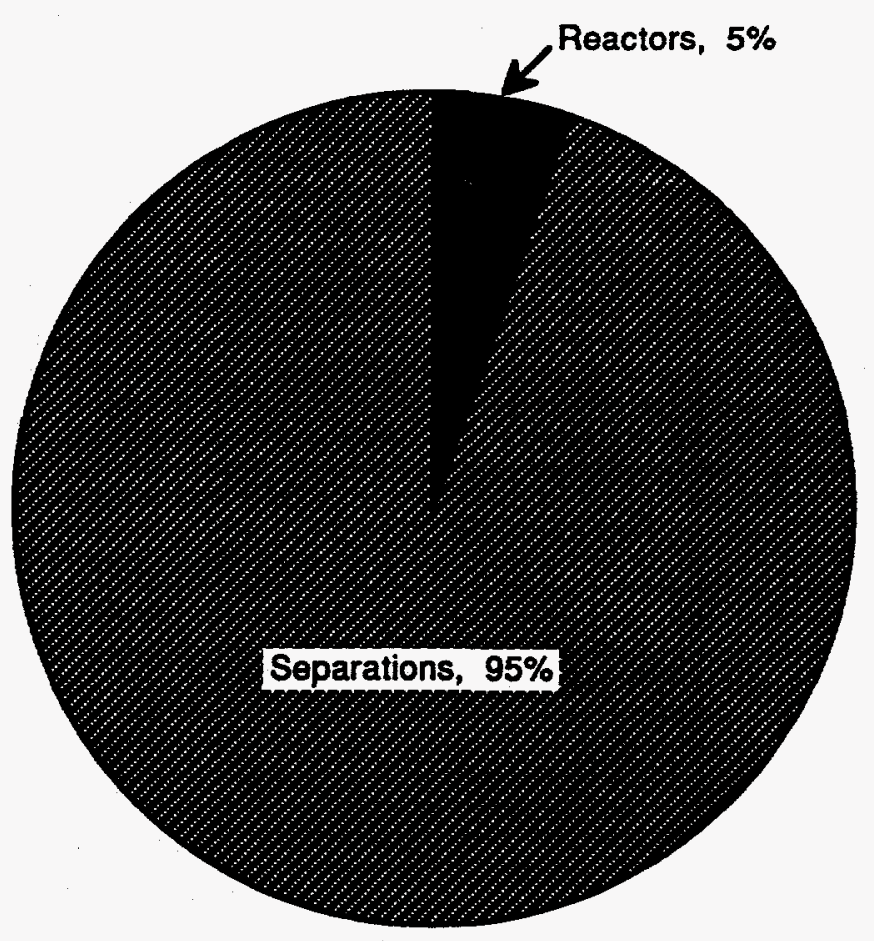


Figure 11B. Aqueous Releases by Facility (Sr-90) Heavy Water \& SRTC; $10 \%$

Separations; $51 \%$

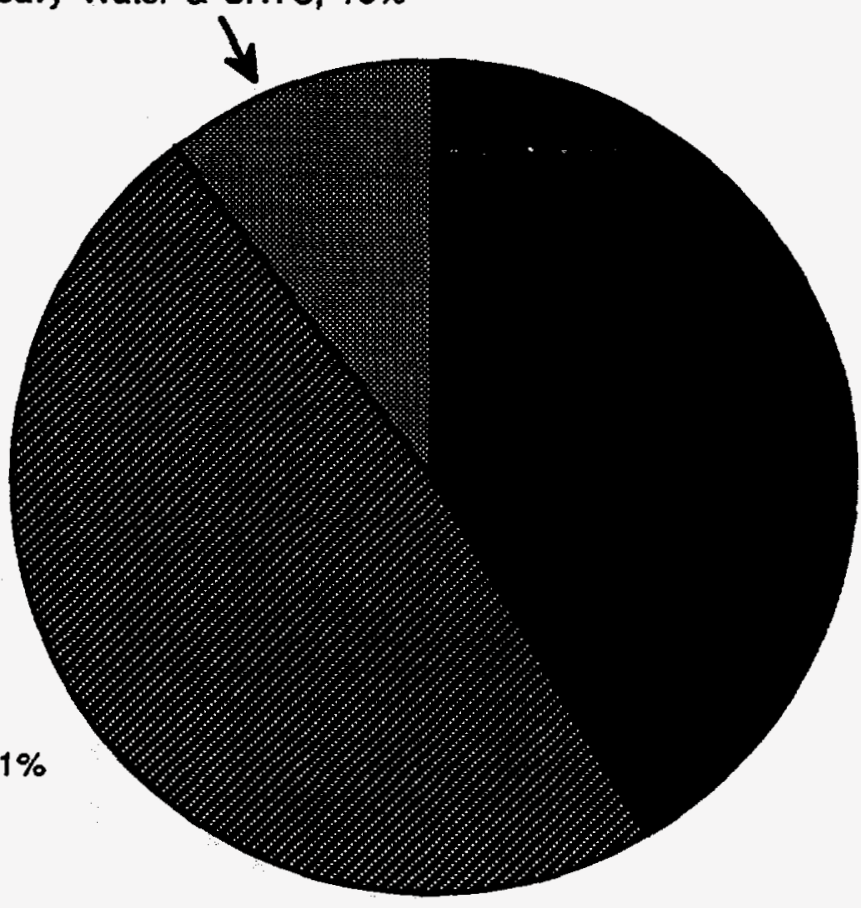

Reactors; $39 \%$ 
Figure 11C. Aqueous Releases by Facility (Pu-239)

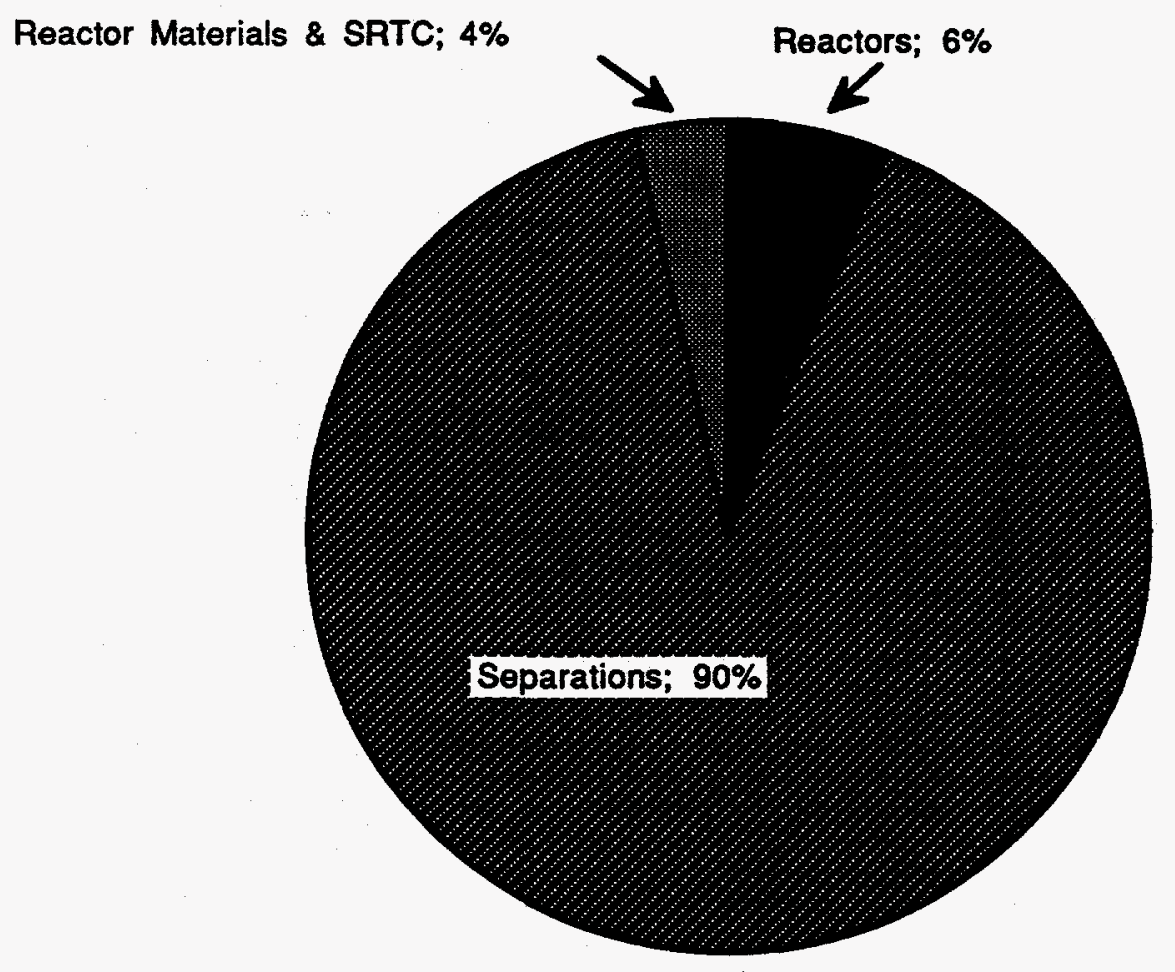


Figure 12A. Population Dose from Atmospheric Releases

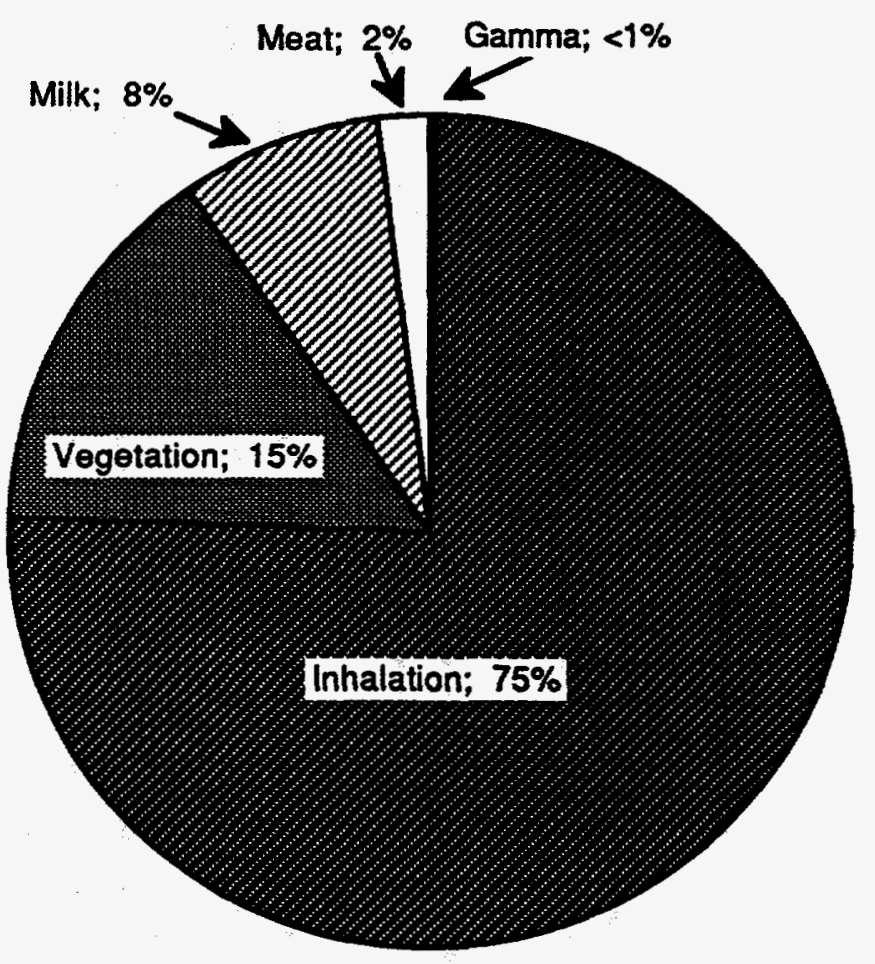


Figure 12B. Population Dose from Atmospheric Releases

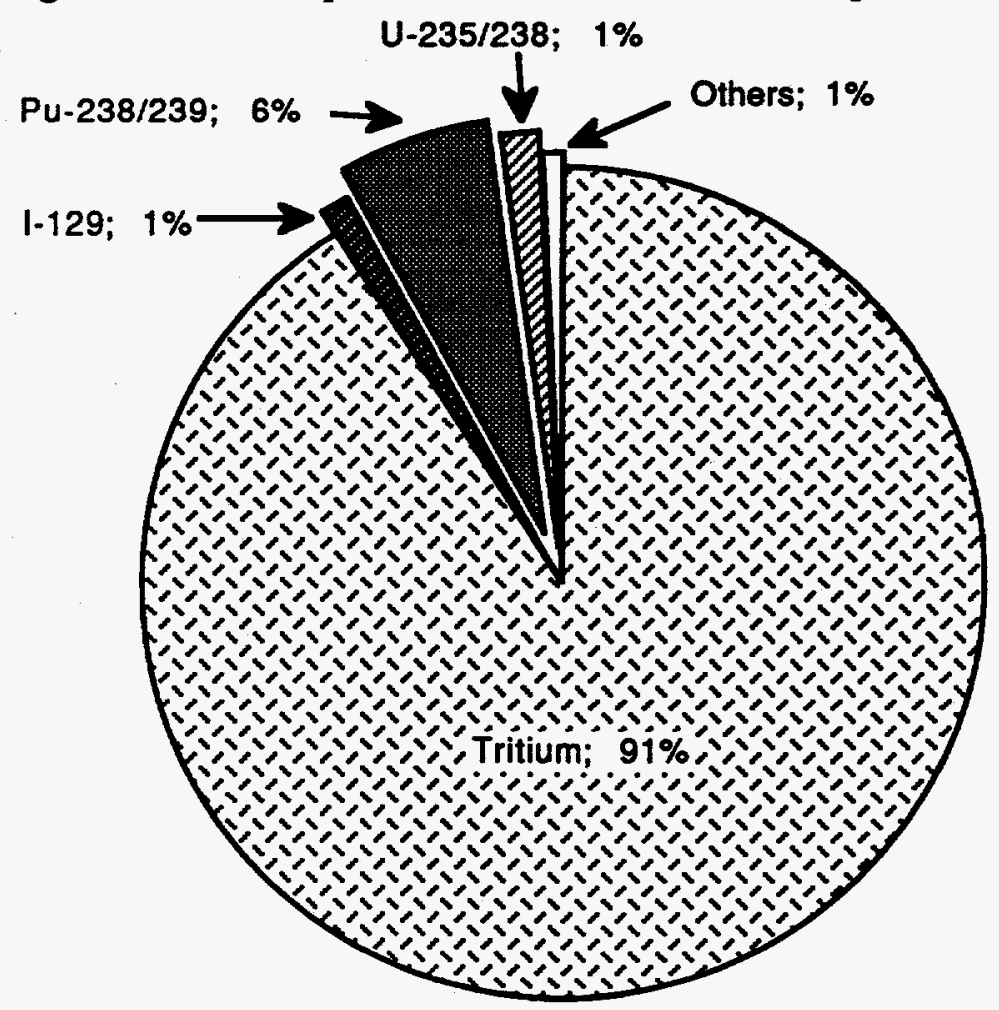


Figure 13. 10-Year History of Individual Dose from Atmospheric Releases

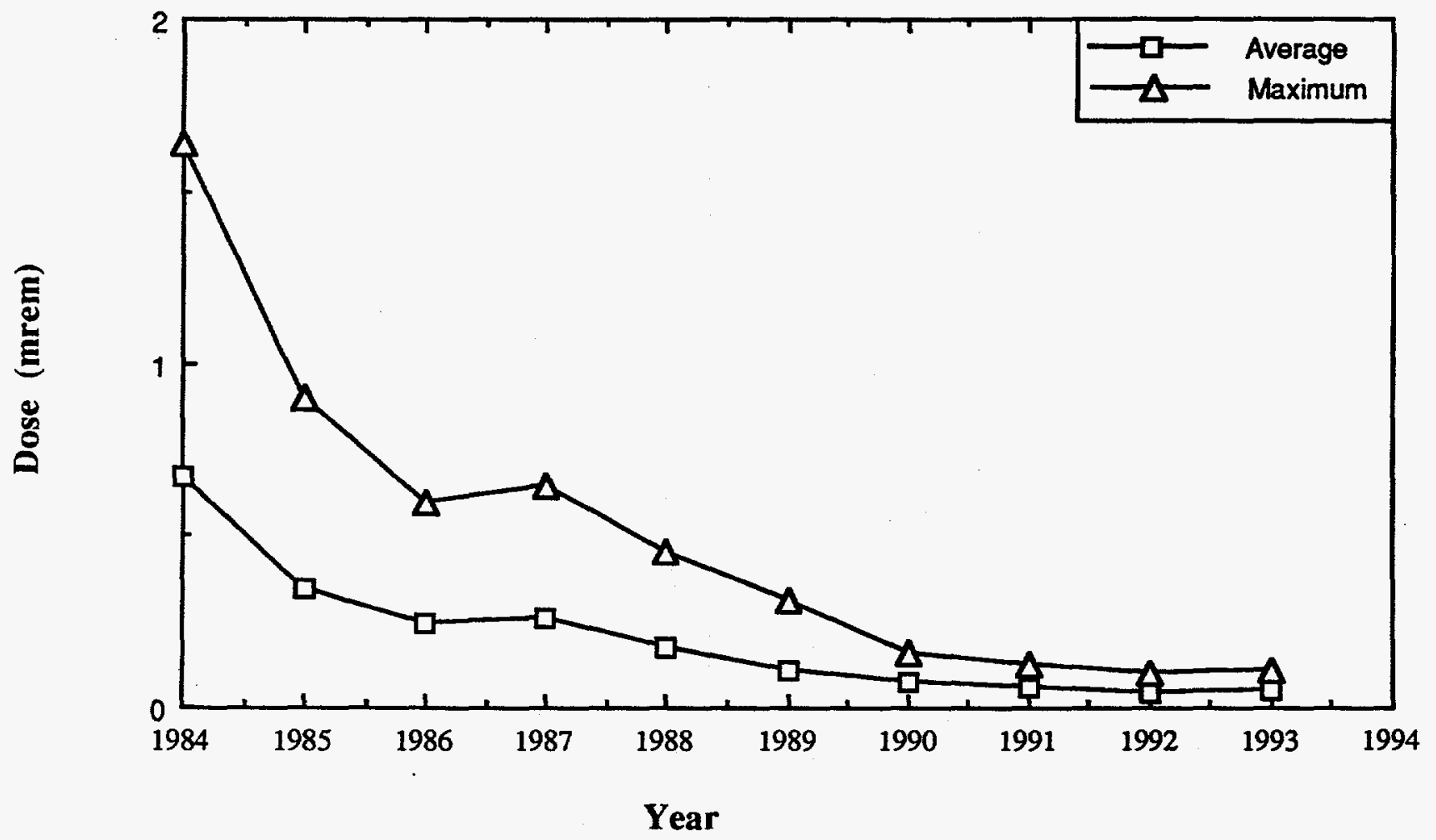


Figure 14. 10-Year History of Population Dose from Atmospheric Releases

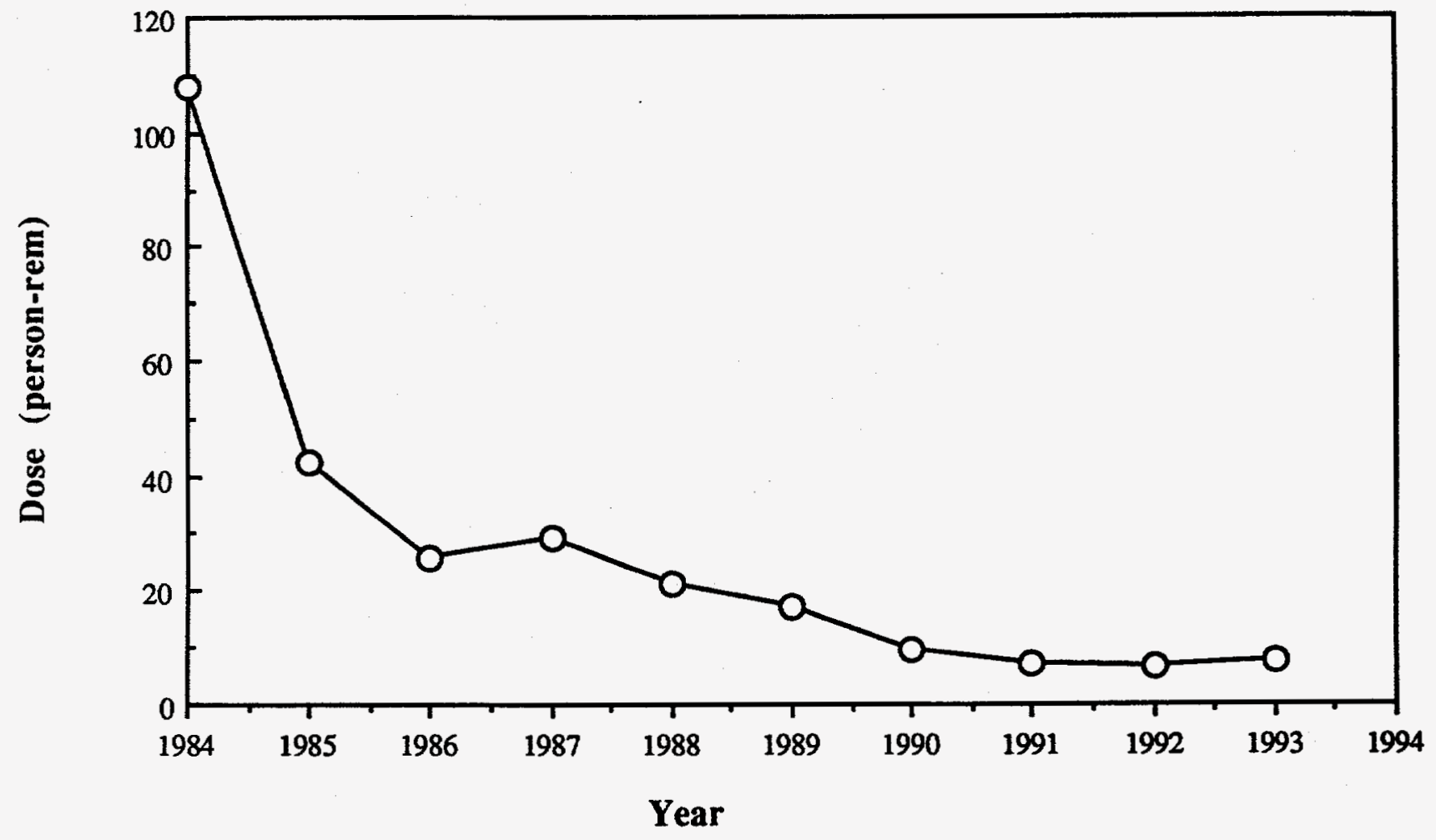


Figure 15A. Population Dose from Liquid Releases.

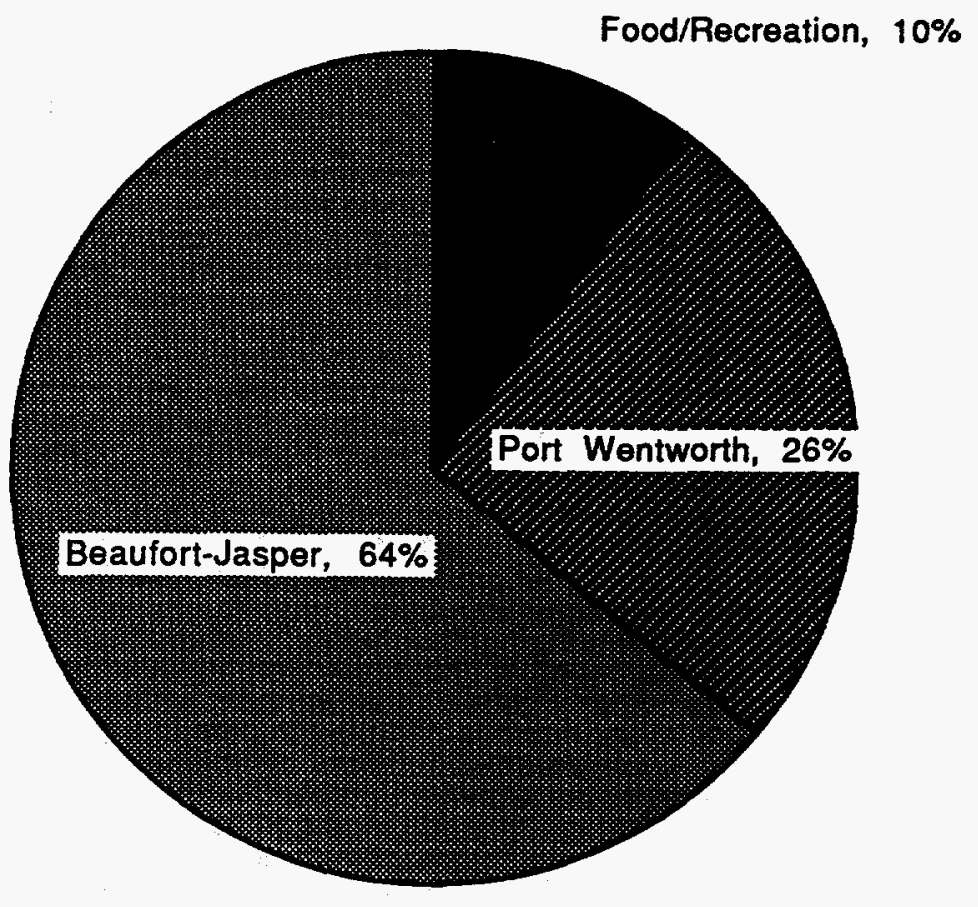


Figure 15B. Population Dose from Liquid Releases

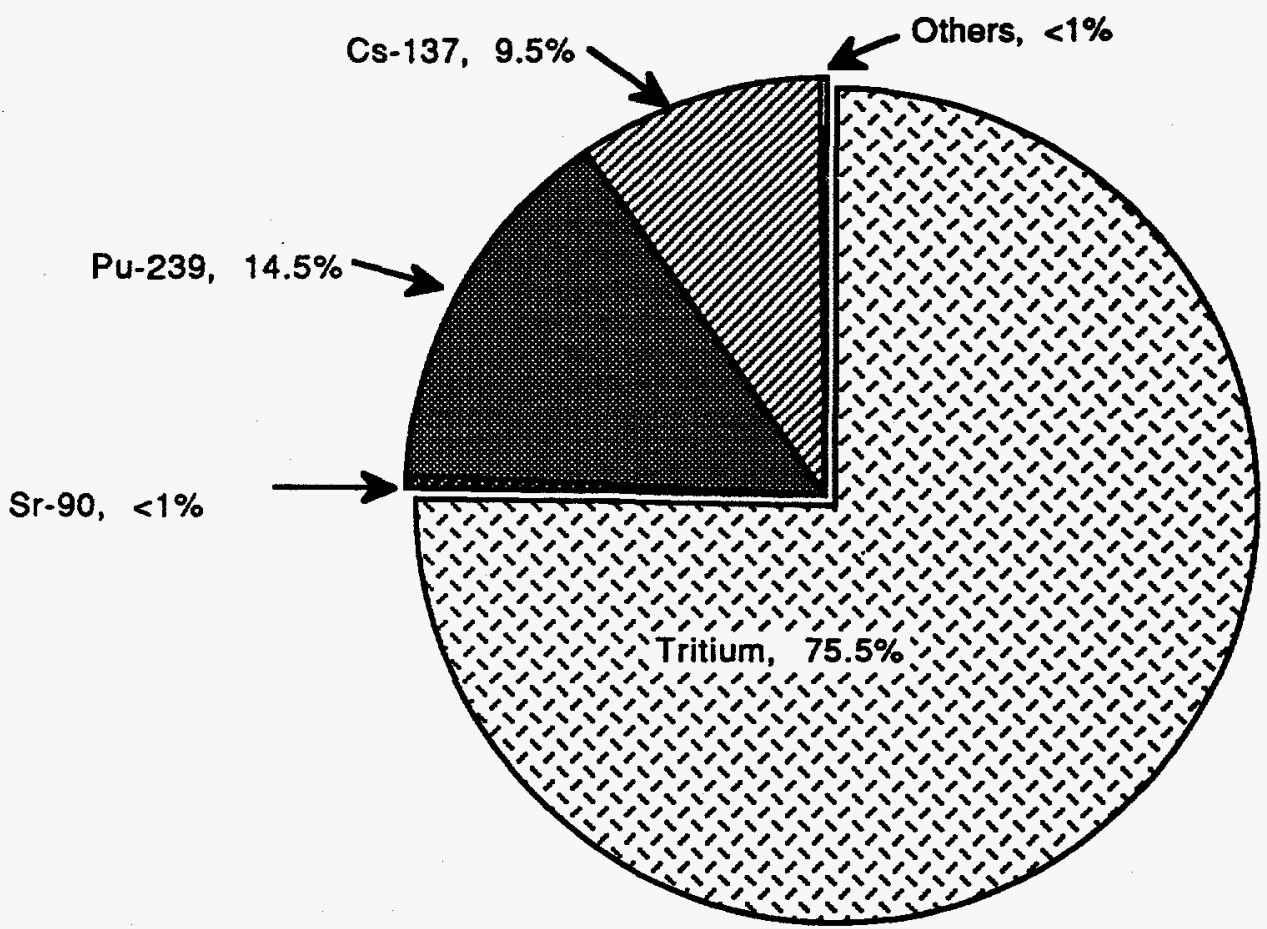


Figure 16. 10-Year History of Maximum Individual Dose from Liquid Releases

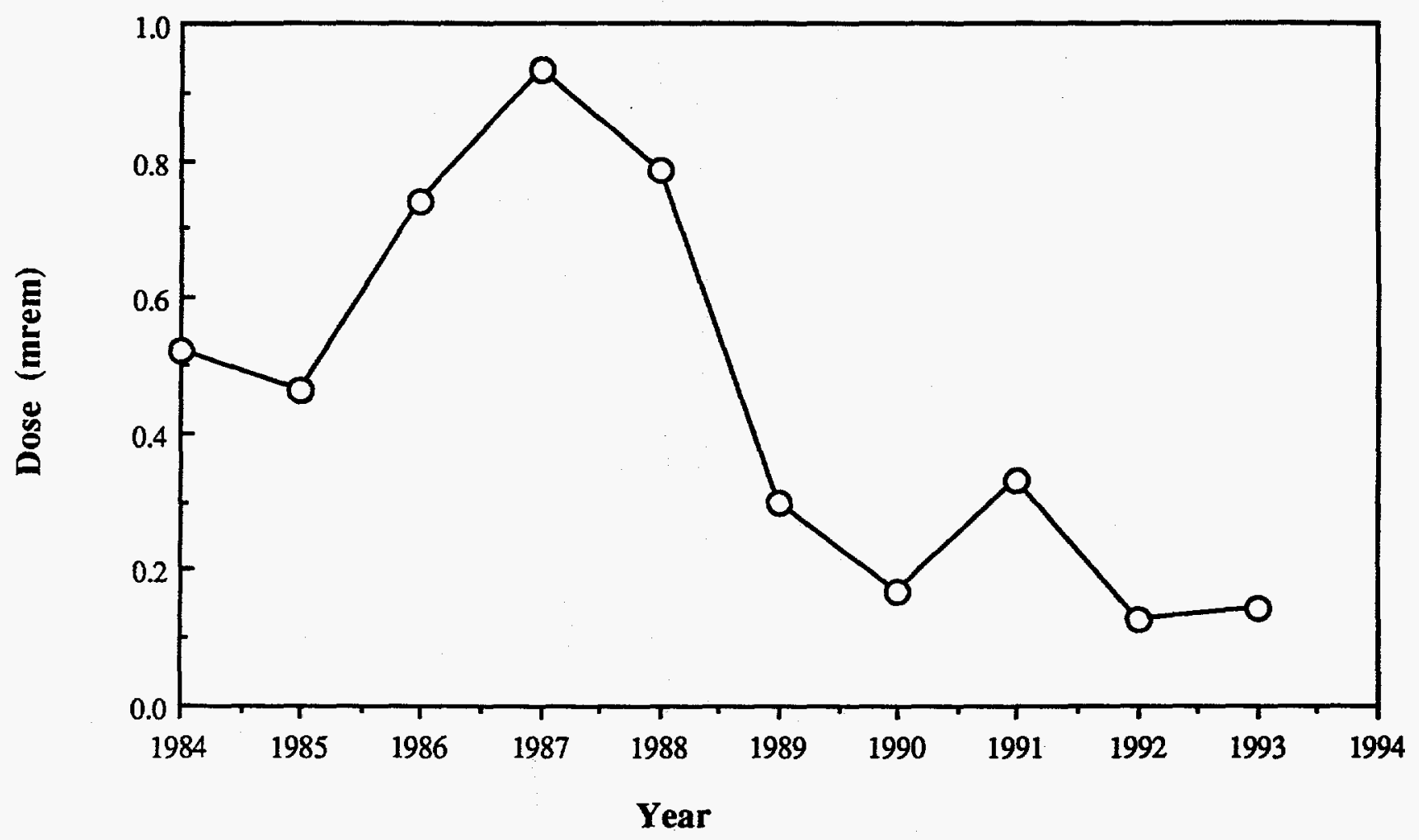


Figure 17. 10-Year History of Population Doses to Savannah River Water Users

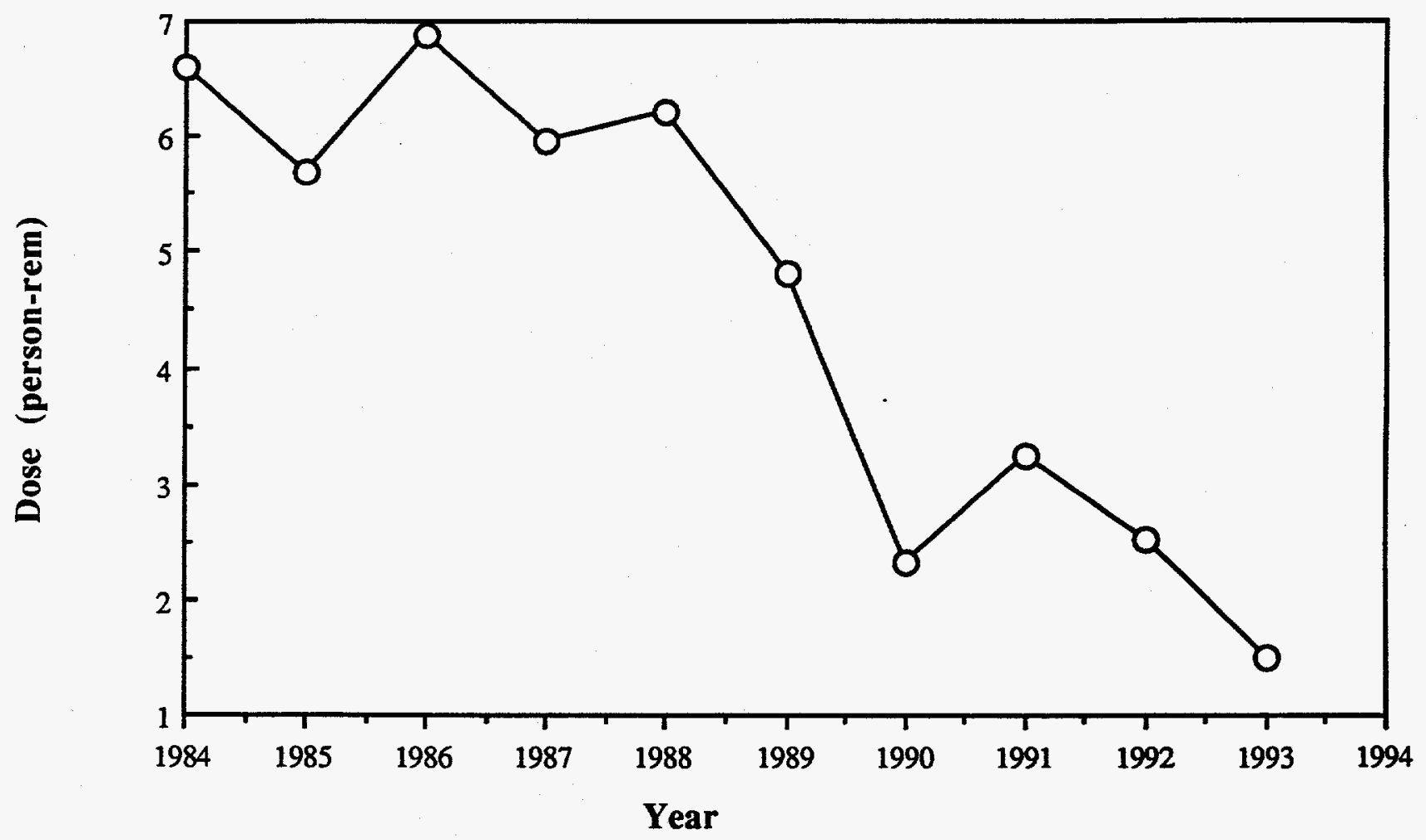




\section{Radiological Impact of 1993 Operations at the Savannah River Site}

Distribution

Addis, R.P., 773-A

Benjamin, R.W., 773-41A

Boni, A.L., 773-A

Boyter, N.C., 730-B

Cadek, F.F., 730-B

Cadotte, B.M., 719-12A

Campbell, R.R., 703-A

Carlton, W.H., 773-A

Clark, A.D., 703-A

Cowen, M.L., 992-1W

Dukes, M.D., 742-A

Emel, W.A., 735-A

Gladden, J.B., 773-42A

Gordon, D.E., 742-A

Gurosik, C., 235-H

Halverson, J.E., 735-A

Hammond, J.S., 703-43A

Hancock, H.A. 779-9A

Heffner, J.D., 735-A

Herrman, J.N., 703-A

Hitchler, M.J., 992-1W

Holtzcheiter, E.W., 773-A

Houston, T.G., 992-3W

Jannik, G.T., 773-A
Jewell, C.E., 705-3C

Jordan, J.F., 703-A

Knight, J.R., 773-A

Loring, W., 735-11A

Maher, R., 703-A

McKibben, J.M., 773-41A

Moore-Shedrow, D.B., 773-A

Musolf, M.E., 992-4W

New, I.B., 704-C

Odum, J.V., 704-196N

O'Kula, K.R., 992-1W

Ortaldo, J.F., 704-S

Papouchado, L.M., 773-A

Roberts, J.S., 742-A

Schwallie, A.L., 703-A

Scott, A.B., 719-4A

Stevenson, D.A. 992-1W

Sujka, M.F., 703-A

Thiessen, C.W., 703-A

Wierzbicki, W.M., 742-A

Wilmarth, W.R., 773-43A

Wood, S., 773-A

Woodward, J.D., 773-A

Wright, G.T., 703-H

SRTC Records(4), 773-A

EDG Records(10), 773-A 